\title{
The Influence of Rootstock Selection on Fruit Quality Attributes of Watermelon
}

\author{
Benny D. Bruton*,1, Wayne W. Fish ${ }^{1}$, Warren Roberts ${ }^{2}$ and Thomas W. Popham ${ }^{3}$ \\ ${ }^{1}$ South Central Agricultural Research Laboratory, Agricultural Research Service, U.S. Department of Agriculture, Lane, \\ OK, 74555, USA \\ ${ }^{2}$ Wes Watkins Agricultural Research and Extension Center, Oklahoma State University, Lane, OK 74555, USA \\ ${ }^{3}$ U. S. Department of Agriculture, Agricultural Research Service, Stillwater, OK, 74075, USA
}

\begin{abstract}
Grafting watermelon (Citrullus lanatus) to control Fusarium wilt has been practiced in Europe, the Middle East, and the Far East for decades. Until recently, grafting watermelon has not been practiced in the United States due to labor costs and land availability. There is some disagreement in the literature as to the effects that grafting has on watermelon fruit quality. This study was designed to determine the effects of grafted watermelon on fruit firmness, lycopene content, and total soluble solids (TSS) using five different rootstocks. When using Cucurbita ficifolia or Cucurbita maxima x Cucurbita moschata hybrid as the rootstock, watermelon fruit consistently had higher fruit firmness values. Other C. maxima x C. moschata hybrids or Lagenaria siceraria rootstocks generally produced lower or more varied fruit firmness values. Grafting increased fruit firmness by as much as $25 \%$ in some cases, but field and year effects were observed. In addition, grafting had no effect on lycopene content or TSS.
\end{abstract}

Furthermore, no off-flavors were detected in fruit from grafted plants, but there was a 5- to 7 day delay in fruit maturity compared to their non-grafted counterpart. Although environment can have a major influence on fruit quality attributes, rootstock selection may be equally important in achieving the desired outcome.

Keywords: Citrullus lanatus, Cucurbita spp., Lagenaria sp., grafting, lycopene, fruit firmness, total soluble solids.

\section{Mention of a trademark, proprietary product, or vendor does not constitute a guarantee or warranty of the product by the USDA and does not imply its approval to the exclusion of other products of vendors that may also be suitable.}

\section{INTRODUCTION}

As a result of the discontinuation of methyl bromide use for fumigation [1], the reduced availability of land for crop rotation, and the increased production of seedless fruit, watermelon (Citrullus lanatus) crops throughout the United States are highly susceptible to the increased incidence of soilborne diseases [2]. For example, approximately $75 \%$ of the watermelons grown in the United States are at risk for Fusarium wilt caused by Fusarium oxysporum f. sp. niveum [3]. Grafting watermelon onto other cucurbit rootstocks for the control of Fusarium wilt and environmental stresses has been practiced in Europe and Asia for many years [4-6]. In contrast, this cultural practice is a new concept for farmers in the United States because of the high costs associated with grafting [7]. For the reasons enumerated above, achieving a higher probability of producing a crop may soon outweigh the added cost of grafting. In addition to disease resistance, grafting may also provide benefits such as greater tolerance to salinity through improved nutrient and water absorption [8]. For the most part, grafting of watermelon onto other Cucurbitaceae rootstocks to provide soilborne disease resistance has been highly successful $[6,8]$. With this success and with more discriminating consumers of watermelon fruit

*Address correspondence to this author at the South Central Agricultural Research Laboratory, Agricultural Research Service, U.S. Department of Agriculture, Lane, OK, 74555, USA; E-mail: bbruton-usda@lane-ag.org comes a second challenge: to produce a high quality fruit from grafted plants that is equal to or better than that of the non-grafted plant.

Watermelon fruit quality does not rely on a single property but depends, rather, upon a cadre of properties of which only a few have been identified and measured. Sugar content appears to be one of the more important quality indices routinely measured by scientists. However, as the marketing of watermelon fruit steadily evolves into its sale as fresh cut, crispness of the fruit and its storage stability become increasingly important. Sensory attributes are highly important, but they are difficult and expensive to objectively quantify. Finally, the ever-growing population of health-conscious consumers is demanding maximal nutritive value in their foods. As an important source of lycopene, watermelon's carotenoid content then becomes a worthy consideration. In attempts to address these fruit quality concerns, previous research has produced somewhat variable results. Grafting onto Cucurbita rootstocks has sometimes been associated with off-flavor development in the fruit [9]. Additionally, several authors have reported that grafting onto various rootstocks increased fruit yield but decreased soluble solids [1012]. In contrast, other scientists found no difference in soluble solids between grafted and non-grafted [13, 14]. Some scion-rootstock combinations reportedly increased carotene [15] and fruit firmness [16]. Taken together, reports to date indicate that depending on the rootstock-scion selection, fruit 
yield and quality attributes may be either positively or negatively affected by grafting [4, 17-19].

Perhaps, the most impressive nutritional attribute of watermelon is lycopene. Red-fleshed watermelon is rich in lycopene, a member of the family of carotenoids that are some of the more important antioxidants in nature [20,21]. There have been many published reports on the health benefits of diets high in lycopene for the prevention of certain types of cancer [22-25] as well as cardiovascular disease [26-28], although some of these claims have been called into question by the US Food and Drug Administration [29]. Regardless, as a result of the increased awareness of the potential virtues of lycopene in human health, consumer demand for lycopene-rich food and nutraceutical products is growing. In contrast to tomato lycopene [30], watermelon lycopene does not require thermal processing to increase its bioavailability in humans [31]. Depending on the cultivar and growing conditions, lycopene can vary from 34 to $112 \mu \mathrm{g} / \mathrm{g}$ fresh-weight [32]. Thus, red-fleshed watermelon is a rich source of readily bioavailable lycopene.

For the most part, previous studies on the effects of grafting were conducted during a single growing season and in a single field or plot. Thus, there has been no comprehensive investigation to evaluate the putative positive or negative effects of grafting on fruit quality as a part of year-to-year and field-to-field variability of growing conditions. The purpose of this study was to evaluate the effects of grafting different watermelon scions onto Cucurbita ficifola, Lagenaria siceraria, or Cucurbita maxima x Cucurbita moschata by quantifying grafting's effects on the resulting fruit quality attributes of flesh firmness and total soluble solids (TSS) as well as on the content of the phytonutrient, lycopene. Furthermore, these grafts were evaluated in separate fields over two growing seasons to gain insight into how fruit quality attributes were influenced by field and seasonal growing conditions.

\section{MATERIALS AND METHODS}

\section{Plant Material}

The experiment was conducted at two locations in 2004 and 2005 at the Lane Research Center at Lane, Oklahoma. Watermelon cvs. 'SS 7167,' 'SS 7177,' 'SS 7187,' 'SF 5244,' and 'SF 800' were used as the scion and were grafted onto one of the five rootstocks 'RS 1330,' 'RS 1332,' 'RS 1420,' 'RS 1421,' or 'RS 1422' (Table 1). In addition to the cultivars listed above, four additional non-grafted watermelon cultivars were used in order to establish baseline data for the fruit quality indices tested. All grafted plants and their non-grafted counterparts were produced by Speedling Inc. of Alamo, TX, using the tongue-approach graft procedure [4]. In 2004, Field \#1600 was planted 17 May and Field \#5100 was planted 24 May. In 2005, Field \#1400 was planted 27 May and Field \#5100 was planted 1 June. The soil was classified as a Bernow sandy loam (fine-loamy, siliceous, thermic (Glossic Paleudalf). Field \#1600 had 71\% sand, $23 \%$ silt, and 3\% clay. Field \#5100 had 53\% sand, $38 \%$ silt, and $9 \%$ clay. Field \#1400 had $71 \%$ sand, $23 \%$ silt, and $6 \%$ clay. Plants were transplanted to the field on $1 \mathrm{~m}$ spacing within the row and $3 \mathrm{~m}$ between rows. Treatments consisted of three replications of 30 plants each arranged in a randomized complete block design. Irrigation was provided using drip-tape and plants were fertilized according to recommendations of Oklahoma State University using standard cultural practices.

\section{Fruit Quality Analysis}

Fruit were obtained from multiple harvests during the month of August in 2004 and 2005. Mature fruit were identified and numbered in the field and subsequently transported to the postharvest facility for further processing. For most treatment combinations, a minimum of 15 fruit were harvested and evaluated as described below. Each fruit was cut perpendicularly to the stem about one fourth of the distance

Table 1. Names, Properties and Source of Plant Material

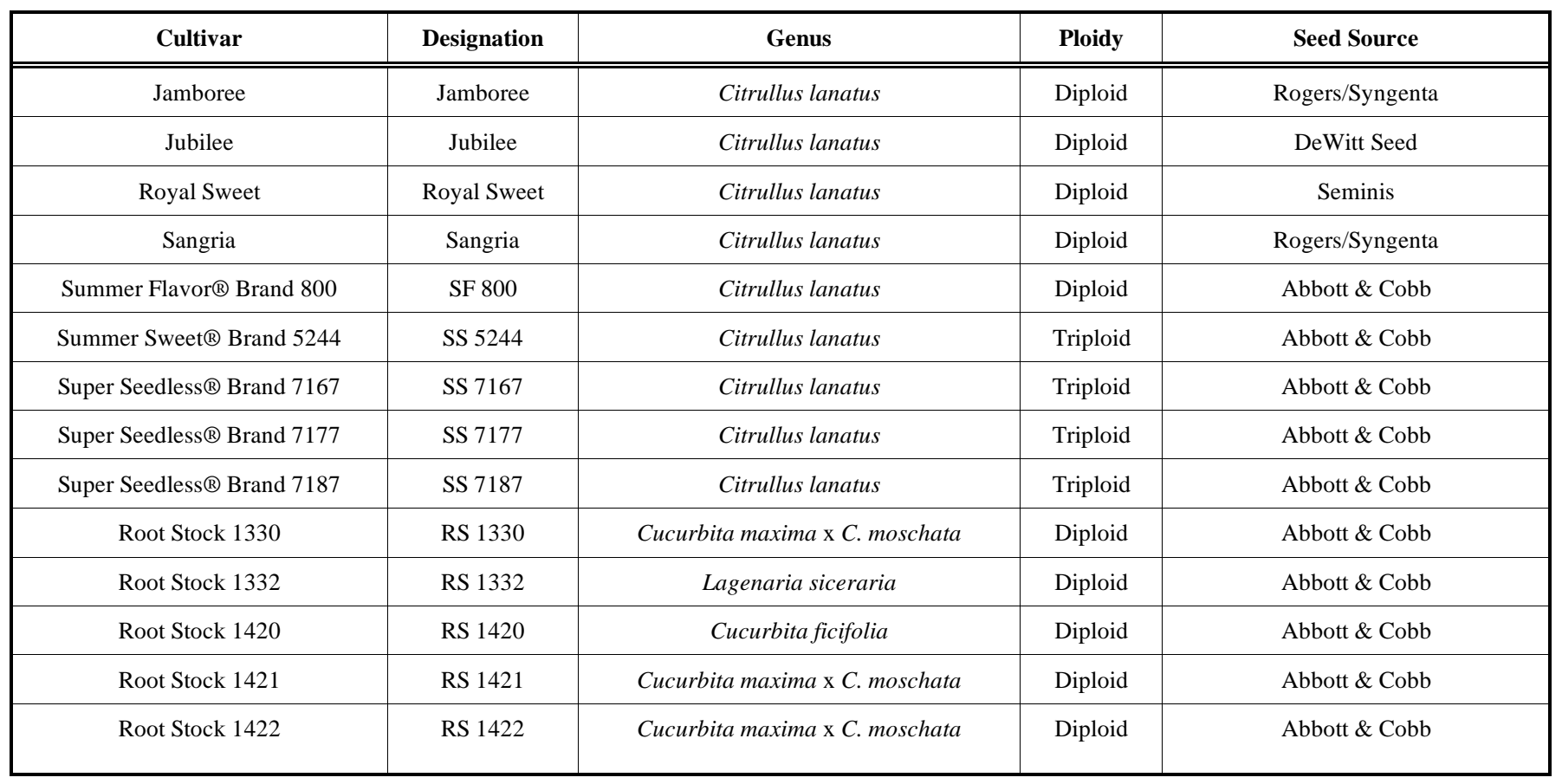


from each end, and the two end sections discarded. Two additional perpendicular slices were made about $5 \mathrm{~cm}$ in thickness. Two cubes $(5 \mathrm{~cm} /$ dimension) were used to determine fruit firmness using an $11.1 \mathrm{~mm}$ diameter head on a Wagner Force Dial FDK 10 (Wagner Instruments, Greenwich, CT) mounted onto a Clarke Metalworker BT1029 drill press (Clarke Metalworker, Perrysburg, OH). Two firmness readings were taken on each cube from opposite sides of the cube. Firmness was measured in lbs force and converted to Newtons (N). The same two cubes were used for determination of total soluble solids using an Atago PR-32 Digital Refractometer (Tokyo, JP). A $3 \mathrm{~mm}$ slice was removed from each cube for determination of total soluble solids (TSS). Two additional cubes were finely ground with a homogenizer (Brinkman Polytron Homogenizer, Westbury, NY) using a PTA-20TS generator for lycopene determination. Samples were assayed for lycopene either immediately after grinding or assayed following storage of the puree at $-20^{\circ} \mathrm{C}$ for less than a week. Lycopene contents of the purees were determined by the low volume hexane extraction method of Fish et al. [33].

\section{Data Analysis}

The initial analysis of variance (ANOVA) of the three fruit quality variables (firmness, lycopene, and total soluble solids) for each field and year included scion and rootstock as main effects and the interaction of scion by rootstock. Because of the significant interaction in 2004, it was decided to do ANOVAs of each rootstock within each field and year in order to compare scions on each rootstock. Likewise, ANOVAs were performed for each scion in each field and year in order to compare rootstocks with the same scion. Additionally, ANOVAs were performed for firmness and lycopene by field within year with a one sided test for increase of 5, 10, 15, 20 or $25 \%$ as a result of grafting. A similar one-sided test was used to determine increases of 5, 10, 15,20 or $25 \%$ between diploid and triploid cultivars. For total soluble solids, the one-sided test was to detect decreases of $1,2,3,4$, or $5 \%$ as a result of grafting. The same analysis was applied to compare diploid and triploid cultivars. Unless otherwise stated, least square means were calculated and presented, and the significance level used for comparisons was $\mathrm{p}<0.05$ with Tukey's adjustment when comparing more than three means.

\section{RESULTS}

\section{Grafting and Fruit Quality: Rationale for Presentation of Results}

During 2004 and 2005, four grafting experiments were established in three different field plots to determine the effects of grafting on the fruit quality indices of firmness, lycopene, and TSS. The cultivars 'Jamboree,' 'Royal Sweet,' 'Sangria,' and 'Jubilee' were included in the study to help establish baseline lycopene, TSS, and fruit firmness values for non-grafted commercial diploids. In 2004, there was a field effect, in which fruit were significantly $(\mathrm{p} \leq 0.05)$ firmer in Field \#1600 than in Field \#5100, in addition to a rootstock effect that was observed in both fields. However, in 2005, there was no field effect, but there were rootstock effects similar to those detected in 2004. Because there was a field effect on the fruit quality attributes tested for one of the crop years, the data are presented separately by field and by year.

Initially, the ANOVAs were applied separately for each year with all the data in each field, using a model that included scion, rootstock and the interaction of scion by rootstock. In 2004, the scion by rootstock interaction was significant for all responses in both fields, except for firmness in field \#1600 where both scion and rootstock main effects were significant. In 2005, scion and rootstock significantly affected fruit firmness and TSS in both fields. For lycopene, the effect of scion was significant in both fields and the effect of rootstock was significant in field \#1400. Scion by rootstock interaction was not significant in either field for any fruit quality attributes (Table 2). For consistency of presentation of fruit quality attributes, Figs. (1-6) shall illustrate the least square means separately for each scionrootstock combination even though the interaction was not significant in 2005. The error bars in the figures represent the pooled standard error, which is appropriate for the data from the entire experiment.

Since analyses were conducted by scion groups or the diploids only, which represented a subset of the data, the least square means and the pooled standard errors may be

Table 2. Probability of a Greater F from Analyses of Variance Done Separately for Each Field in Each Year

\begin{tabular}{|c|c|c|c|c|c|}
\hline & Year & 2004 & & 2005 & \\
\hline \multirow{2}{*}{ Firmness (N) } & Root stock & $<0.0001$ & $<0.0001$ & $<0.0001$ & $<0.0001$ \\
\hline & Scion $\mathrm{X}$ root stock & 0.4928 & 0.0020 & 0.8141 & 0.9479 \\
\hline \multirow{2}{*}{ Lycopene $(\mu \mathrm{g} / \mathrm{g})$} & Root stock & 0.4573 & $<0.0001$ & 0.0126 & 0.1654 \\
\hline & Scion $\mathrm{X}$ root stock & 0.0002 & 0.0008 & 0.1151 & 0.2516 \\
\hline \multirow[t]{2}{*}{ Sugar $(\%)$} & Scion & 0.0183 & $<0.0001$ & $<0.0001$ & $<0.0001$ \\
\hline & Root stock & 0.6644 & $<0.0001$ & 0.0005 & 0.0058 \\
\hline
\end{tabular}

Shaded cells indicate significance at $\mathrm{p} \leq 0.05$. 
Table 3. Comparison of Fruit Quality Attributes of Diploid Versus Triploid Watermelon Cultivars

\begin{tabular}{|c|c|c|c|c|c|c|c|c|c|c|}
\hline \multicolumn{5}{|c|}{ FIRMNESS (N) } & $\begin{array}{l}\text { p-Value for } \\
\text { Difference }\end{array}$ & \multicolumn{5}{|c|}{ p-Value for One-Sided Test of Increase of at Least } \\
\hline \multirow{2}{*}{2004} & & triploid & 12.8 & 5.2 & $<0.0001$ & $<0.0001$ & $<0.0001$ & $<0.0001$ & $<0.0001$ & $<0.0001$ \\
\hline & 5100 & diploid & 7.4 & & & & & & & \\
\hline \multirow[t]{4}{*}{2005} & 1400 & diploid & 8.3 & & & & & & & \\
\hline & & triploid & 10.4 & 2.1 & 0.0001 & 0.0015 & 0.0130 & 0.0835 & & \\
\hline & 5100 & diploid & 7.9 & & & & & & & \\
\hline & & triploid & 10.4 & 2.5 & $<0.0001$ & $<0.0001$ & 0.0009 & 0.0091 & 0.0635 & \\
\hline
\end{tabular}

\begin{tabular}{|c|c|c|c|c|c|c|c|c|c|c|}
\hline \multicolumn{5}{|c|}{ LYCOPENE $(\mu \mathrm{g} / \mathrm{g})$} & \multirow{2}{*}{$\begin{array}{l}\text { p-Value for } \\
\text { Difference }\end{array}$} & \multicolumn{5}{|c|}{ p-Value for One-Sided Test of Increase of at Least } \\
\hline Year & Field & Ploidy & LS Mean & Difference & & $5 \%$ & $10 \%$ & $15 \%$ & $20 \%$ & $25 \%$ \\
\hline \multirow{2}{*}{2004} & & triploid & 55.2 & 2.8 & 0.1641 & & & & & \\
\hline & 5100 & diploid & 57.3 & & & & & & & \\
\hline \multirow[t]{3}{*}{2005} & 1400 & diploid & 49.7 & & & & & & & \\
\hline & & triploid & 52.7 & 3.0 & 0.1023 & & & & & \\
\hline & 5100 & diploid & 65.6 & & & & & & & \\
\hline
\end{tabular}

\begin{tabular}{|c|c|c|c|c|c|c|c|c|c|c|}
\hline \multicolumn{5}{|c|}{ SOLUBLE SOLIDS (\%) } & $\begin{array}{l}\text { p-Value for } \\
\text { Difference }\end{array}$ & \multicolumn{5}{|c|}{ p-Value for One-Sided Test of Decrease of at Least } \\
\hline \multirow{2}{*}{2004} & & triploid & 9.9 & -0.3 & 0.1050 & & & & & \\
\hline & 5100 & diploid & 10.7 & & & & & & & \\
\hline \multirow[t]{4}{*}{2005} & 1400 & diploid & 11.6 & & & & & & & \\
\hline & & triploid & 11.5 & -0.2 & 0.3533 & & & & & \\
\hline & 5100 & diploid & 11.9 & & & & & & & \\
\hline & & triploid & 12.2 & 0.3 & 0.0612 & & & & & \\
\hline
\end{tabular}

*Test was for decrease. This change was an increase.

Shaded block indicates statistical significance at $\mathrm{p} \leq 0.05$ level.

different because the data set is a smaller subset of the whole. These analyses of subsets were applied because of the significant scion by rootstock interaction observed in 2004 . The same subset analysis was used for 2005 even though the interaction was not significant in that year.

In all fields in both years, firmness was significantly different between diploid and triploid cultivars (Table 3). Firmness of triploid fruit was $10 \%$ to $25 \%$ higher than for diploid fruit. Lycopene was significantly different in field \#5100, but was less than $5 \%$ greater and was not different in fields $\# 1600$ and \#1400. With respect to TSS, the differences were less than $1 \%$ or not significant between diploids and triploids.

Since a statistically significant crop-year effect was observed for the fruit quality parameters that were measured, it was deemed important to present daily maximum tempera- 


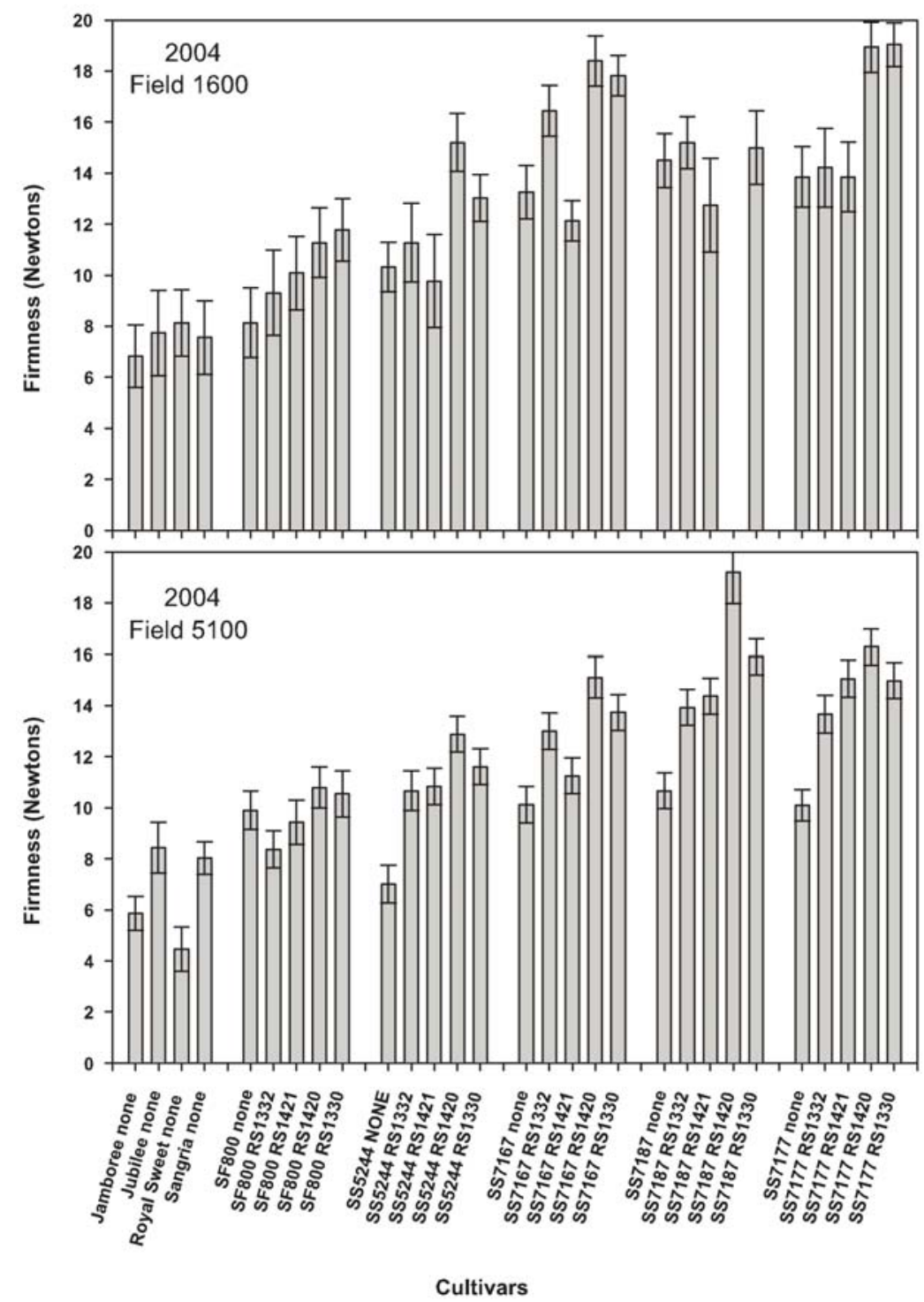

Fig. (1). Fruit firmness measurements from grafted and non-grafted watermelon plants in 2004. Method of measurement is described in Materials and Methods. Bars represent pooled standard errors at $\mathrm{p} \leq 0.05$.

ture, cumulative daily sunlight, and rainfall at the Lane, OK Research Station for the 2004 and 2005 growing seasons. These Mesonet data are presented on a day-to-day basis in Appendix Fig. (1). Appendix Table 1 summarizes these data as mean maximum temperature, average daily sunlight, and total rainfall amount in 30 day blocks from the date of planting for each field and each year. Maximum temperatures averaged about $3^{\circ} \mathrm{C}$ cooler during the 2004 growing season than during the 2005 growing season. The average solar radiation for the first 60 days in 2004 was about $3.7 \mathrm{MJ} / \mathrm{m}^{2}$ less than in 2005. Additionally, there was about $36 \%$ greater rainfall during the 2004 growing season $(32.4 \mathrm{~cm})$ than during the 2005 growing season $(20.7 \mathrm{~cm})$. Although there were widely different temperatures and rainfall frequency and amounts during the cropping season of 2004 and 2005, no attempt was made to ascribe fruit responses as a function of single or combined environmental factors. In each year of the study, supplemental irrigation was applied when needed. Visual and tactile observations of soil and plant moisture were used to determine the need for and timing of such irri- gation. When needed, irrigation was applied through drip irrigation systems for 2-4 hours, or until the area of soil in and along the plant row was near saturation.

\section{Year 2004}

\section{Fruit Firmness}

The firmness responses to grafting by watermelon produced in two separate fields in 2004 are presented in Fig. (1), Table 4, and Appendix Tables 2 and 4. In field \#1600, firmness of fruit from non-grafted plants ranged from 14.5 to 6.8 $\mathrm{N}$ as compared to 19.0 to $9.3 \mathrm{~N}$ in fruit from grafted plants (Fig. 1, Appendix Tables 2 and 4). Fruit firmness among non-grafted diploids did not differ significantly from each other with an overall average of $7.0 \mathrm{~N}$. Although the nongrafted diploid 'SF800' had a similar least square mean (8.1 $\mathrm{N})$ to the other non-grafted diploids, when grafted onto rootstock 'RS 1330' the resulting fruit had a firmness of $11.8 \mathrm{~N}$. Fruit from all grafted triploids generally exhibited an increase in fruit firmness as compared to their non-grafted 
Table 4. Comparison and Percentage Change in Fruit Firmness (N) from Grafted and Non-Grafted Watermelon Plants Grown in Two Fields Over Two Years at Lane, OK

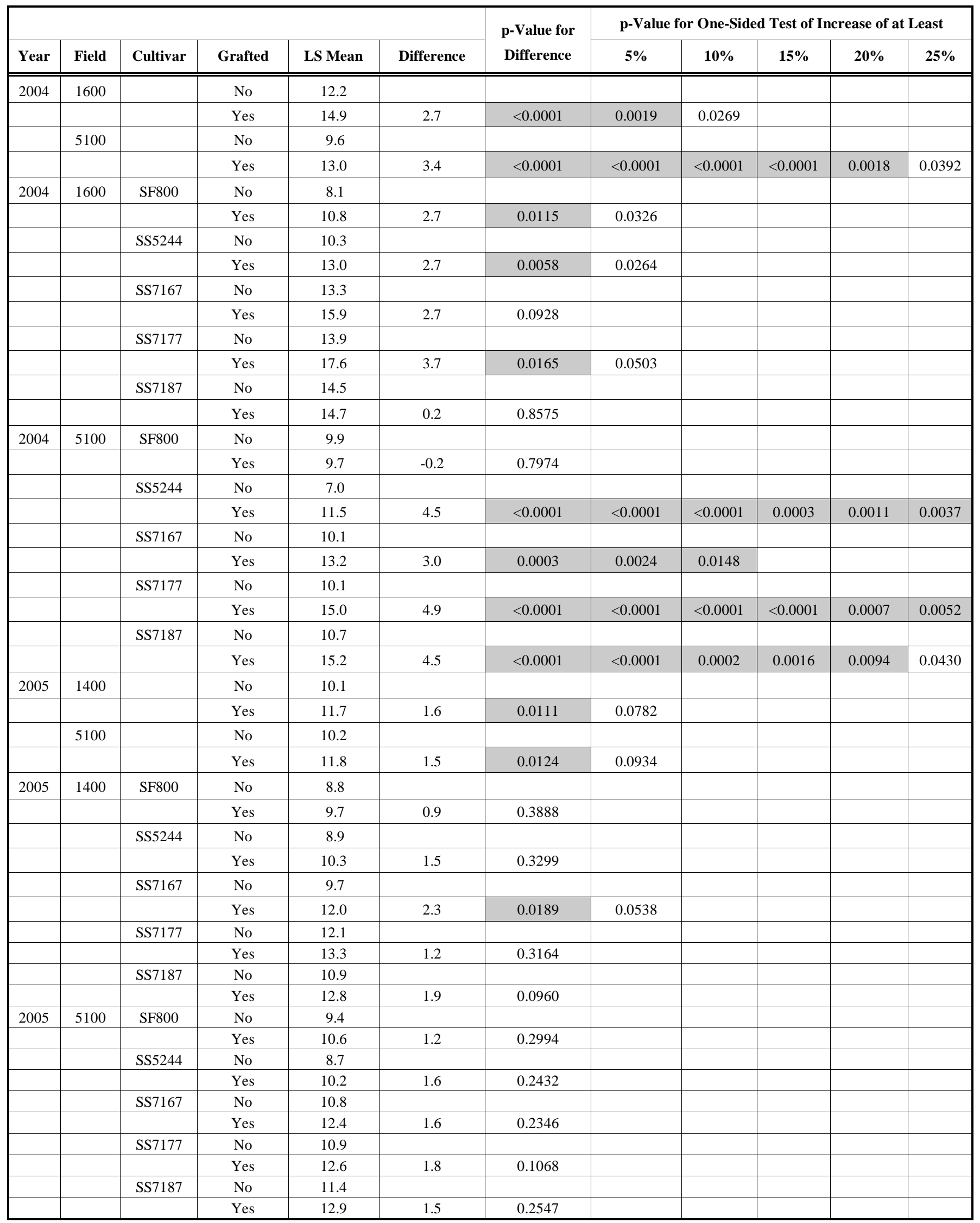




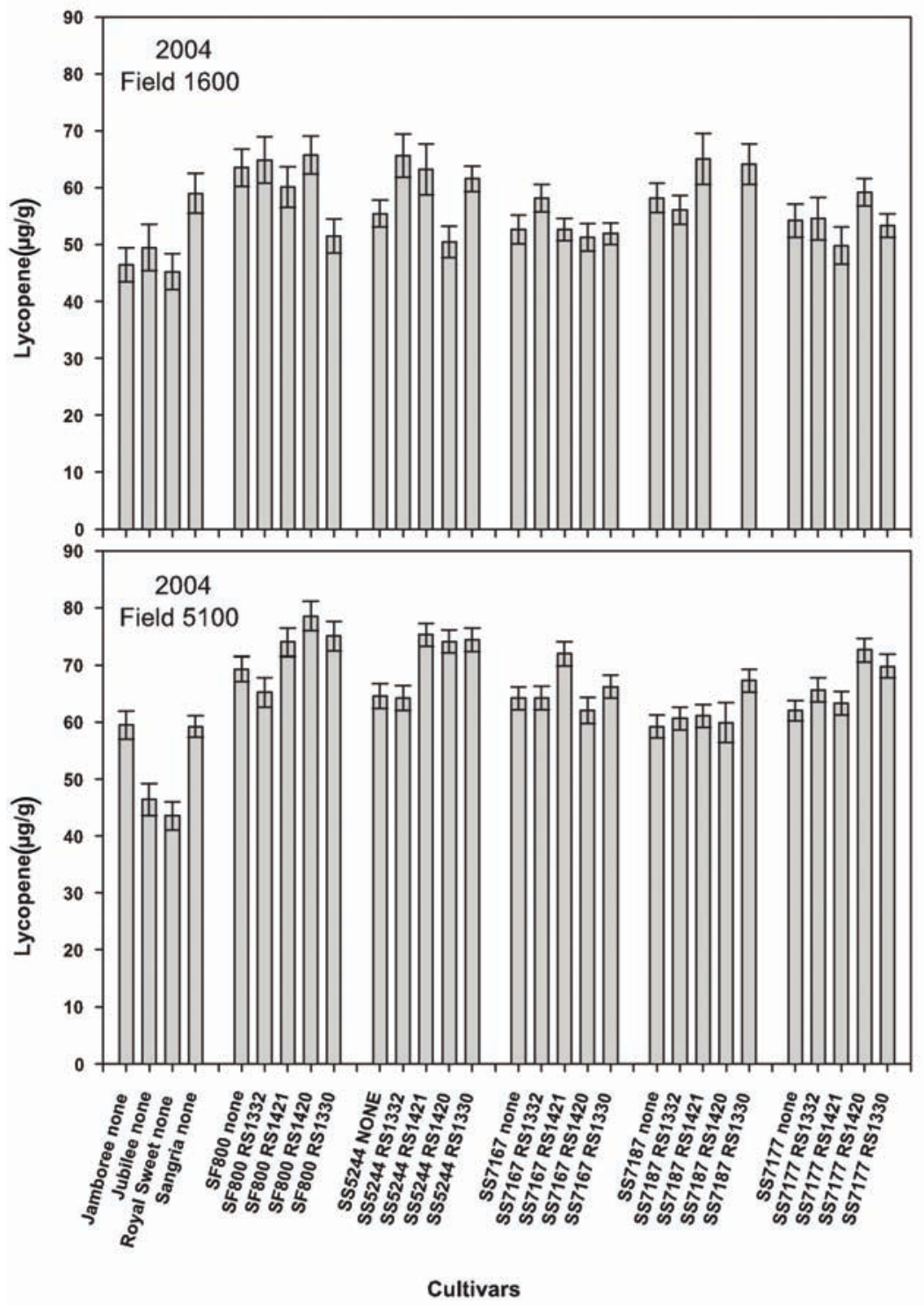

Fig. (2). Lycopene content ( $\mu \mathrm{g} / \mathrm{g}$ tissue) in watermelon fruit from grafted and non-grafted plants in 2004. Method of measurement is described in Materials and Methods. Bars represent pooled standard errors at $\mathrm{p} \leq 0.05$.

counterpart. The two rootstocks that consistently produced higher fruit firmness values were 'RS 1330' (C. maxima x $C$. moschata) or 'RS 1420' (C. ficifolia) except when 'SS7187' was the scion (Fig. 1). Over all scions, there was a significant grafting effect that resulted in increasing fruit firmness by $5 \%$ (Table 4 ).

In field \#5100, firmness ranged from 10.7 to $4.5 \mathrm{~N}$ for fruit from non-grafted plants while the range for fruit firmness from grafted plants was 19.2 to $8.4 \mathrm{~N}$ (Fig. 1, Appendix Tables 2 and 4). Although the non-grafted diploids, 'Jubilee' and 'Sangria,' exhibited similar fruit firmness values as in field \#1600, 'Jamboree' and 'Royal Sweet' fruit were significantly different when compared to 'Jubilee' and 'Sangria.' For the diploid SF800 there was no significant difference in firmness of fruit with respect to grafted or nongrafted plants. Fruit of grafted-triploid plants consistently exhibited significantly higher firmness values than their nongrafted counterparts. As a rule, fruit from scions grafted onto rootstocks 'RS 1330' or 'RS 1420' produced fruit with higher fruit firmness values when compared to fruit from scions grafted onto rootstocks 'RS 1332' (L. siceraria) or 'RS 1421' (C. maxima X C. moschata). Considering all scions together in field $\# 5100$, there was a significant grafting effect that resulted in increasing fruit firmness by $20 \%$ (Table 4). There was no grafting effect for 'SF800.' However, grafting produced a $25 \%$ increase in fruit firmness in cultivars 'SS5244' and 'SS7177,' a 20\% increase in 'SS7187,' and a $10 \%$ increase in 'SS7167' (Table 4).

\section{Lycopene}

The lycopene contents of grafted and control watermelons produced in fields 1600 and 5100 during 2004 are summarized in Fig. (2), Table 5, and Appendix Tables 2 and 4. In field \#1600, lycopene content for 'Sangria' was significantly ( $\mathrm{p} \leq 0.05)$ greater than for 'Jamboree' or 'Royal Sweet' ranging from 58.0 to $45.2 \mu \mathrm{g} / \mathrm{g}$ of tissue (Fig. 2). There were 
Table 5. Comparison of Fruit Lycopene ( $\mu \mathrm{g} / \mathrm{g})$ from Grafted and Non-Grafted Watermelon Plants Grown in Two Fields Over Two Years at Lane, OK

\begin{tabular}{|c|c|c|c|c|c|c|c|c|c|c|c|}
\hline Year & Field & Cultivar & Grafted & LS Mean & Difference & $\begin{array}{l}\text { p-Value for } \\
\text { Difference }\end{array}$ & \multicolumn{5}{|c|}{ p-Value for One-Sided Test of Increase of at Least } \\
\hline \multirow[t]{4}{*}{2004} & 1600 & & No & 56.3 & & & & & & & \\
\hline & & & Yes & 56.2 & 0.0 & 0.9835 & & & & & \\
\hline & 5100 & & No & 63.6 & & & & & & & \\
\hline & & & Yes & 68.3 & 4.7 & $<0.0001$ & 0.1964 & & & & \\
\hline \multirow{5}{*}{2004} & & SS5244 & No & 55.4 & & & & & & & \\
\hline & & & Yes & 59.2 & 3.7 & 0.2107 & & & & & \\
\hline & & SS7167 & No & 52.7 & & & & & & & \\
\hline & & & Yes & 53.2 & 0.6 & 0.8564 & & & & & \\
\hline & & SS7177 & No & 54.2 & & & & & & & \\
\hline \multirow[t]{9}{*}{2004} & 5100 & SF800 & No & 69.3 & & & & & & & \\
\hline & & & Yes & 73.2 & 3.9 & 0.1730 & & & & & \\
\hline & & SS5244 & No & 64.6 & & & & & & & \\
\hline & & & Yes & 72.3 & 7.7 & 0.0023 & 0.0741 & & & & \\
\hline & & SS7167 & No & 64.2 & & & & & & & \\
\hline & & & Yes & 66.3 & 2.1 & 0.3965 & & & & & \\
\hline & & SS7177 & No & 62.0 & & & & & & & \\
\hline & & & Yes & 68.0 & 5.9 & 0.0037 & 0.1616 & & & & \\
\hline & & SS7187 & No & 59.3 & & & & & & & \\
\hline \multirow{8}{*}{2005} & & SS5244 & No & 56.6 & & & & & & & \\
\hline & & & Yes & 60.3 & 3.7 & 0.2811 & & & & & \\
\hline & & SS7167 & No & 49.6 & & & & & & & \\
\hline & & & Yes & 49.0 & -0.6 & 0.8246 & & & & & \\
\hline & & SS7177 & No & 50.4 & & & & & & & \\
\hline & & & Yes & 53.1 & 2.7 & 0.3018 & & & & & \\
\hline & & SS7187 & No & 54.2 & & & & & & & \\
\hline & & & Yes & 55.7 & 1.5 & 0.6715 & & & & & \\
\hline \multirow[t]{10}{*}{2005} & 5100 & SF800 & No & 74.6 & & & & & & & \\
\hline & & & Yes & 75.1 & 0.4 & 0.8982 & & & & & \\
\hline & & SS5244 & No & 76.1 & & & & & & & \\
\hline & & & Yes & 74.8 & -1.4 & 0.6339 & & & & & \\
\hline & & SS7167 & No & 66.5 & & & & & & & \\
\hline & & & Yes & 67.4 & 0.9 & 0.8219 & & & & & \\
\hline & & SS7177 & No & 68.3 & & & & & & & \\
\hline & & & Yes & 67.9 & -0.4 & 0.9292 & & & & & \\
\hline & & SS7187 & No & 71.9 & & & & & & & \\
\hline & & & Yes & 69.2 & -2.7 & 0.2672 & & & & & \\
\hline
\end{tabular}




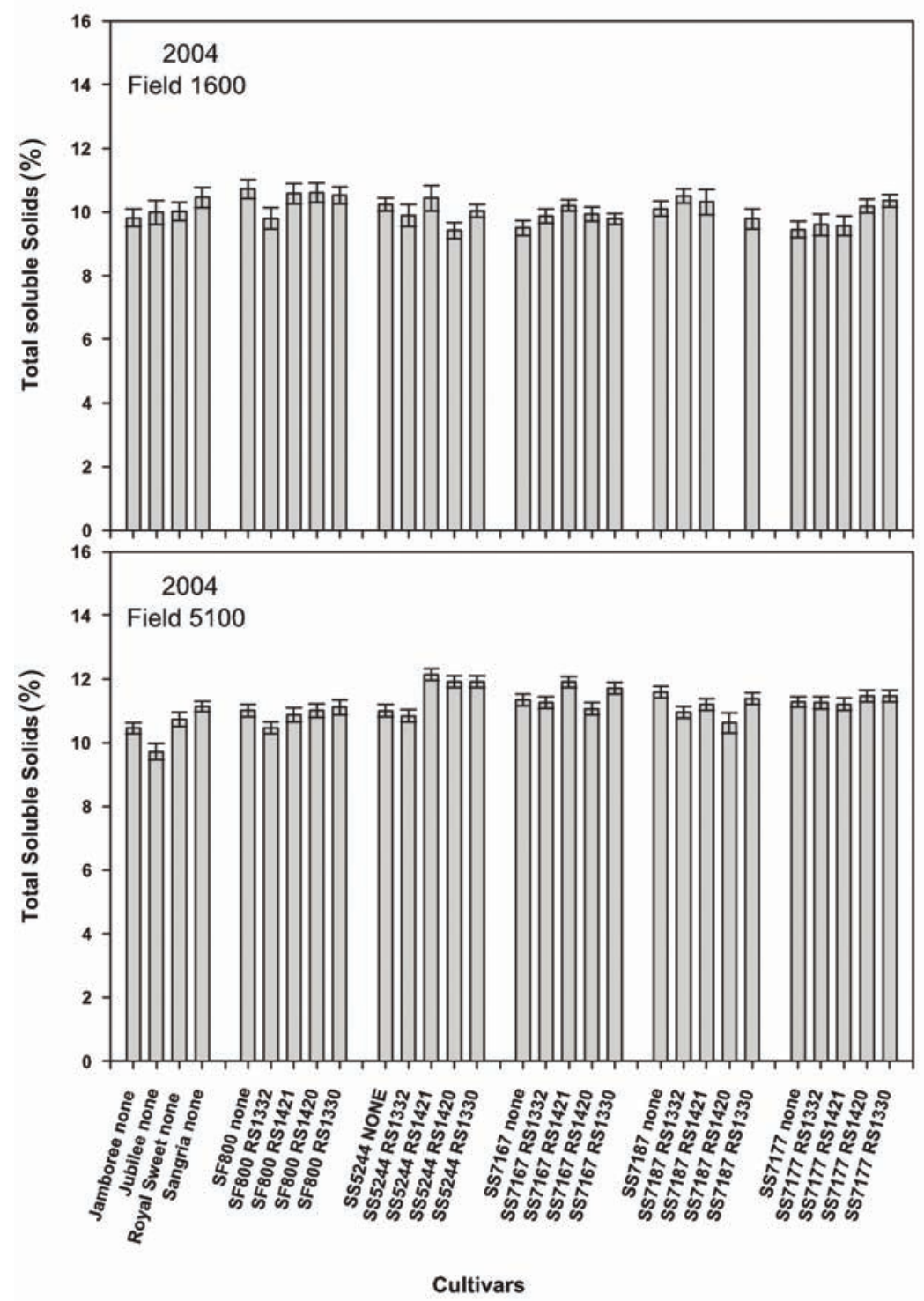

Fig. (3). Total soluble solids in watermelon fruit from grafted and non-grafted plants in 2004. Method of measurement is described in Materials and Methods. Bars represent pooled standard errors at $\mathrm{p} \leq 0.05$.

no differences within cultivars used as scions 'SS7167,' 'SS7177,' or 'SS7187' due to grafting (Fig. 2, Table 5) and a minimal grafting effect on lycopene when evaluating all scions (Appendix Tables 2 and $\mathbf{4}$ ).

In field \#5100, lycopene content ranged from 75.5 to $43.6 \mu \mathrm{g} / \mathrm{g}$ of tissue, which was generally higher than lycopene values observed in field \#1600. There were no differences in lycopene content between grafted and non-grafted 'SS7187.' Scions 'SF800,' 'SF5244,' 'SS7167' and 'SS7177' exhibited a scion by rootstock interaction cited earlier (Fig. 2, Appendix Table 2). Although significant differences were occasionally observed, there was never a change in lycopene content by as much as $5 \%$ in either field (Table 5).

\section{Total Soluble Solids}

Total soluble solids for watermelons from the 2004 harvest of fields 1600 and 5100 are presented in Fig. (3), Table 6, and Appendix Tables 2 and 4. In field \#1600, TSS ranged between 10.7 and 9.4\%. For all scions except 'SF5244,' there were no significant effects due to grafting (Fig. 3, Appendix Tables 2 and 4). In field \#5100, TSS ranged between 12.1 and $9.7 \%$ (Fig. 3, Appendix Tables 2 and 4). 'Sangria' (11.1) had significantly $(\mathrm{p} \leq 0.05)$ more TSS as compared to the other non-grafted diploids. There was no difference in TSS content within the grafted or non-grafted 'SF800,' 'SS7177,' or 'SS7187.' Though there were statistically significant differences in TSS for scions 'SF800' and 'SF5244,' these differences probably were not relevant but due to the very low standard errors found in the TSS data for both fields. Regardless of grafting, there was never as much as a $1 \%$ decrease in TSS in either field (Table 6).

\section{Year 2005}

\section{Fruit Firmness}

In crop year 2005, the fruit firmness of non-grafted plants from field 1400 ranged from 12.0 to $7.5 \mathrm{~N}$ while the range of fruit firmness of grafted plants from the same field was 15.4 
Table 6. Comparison of Fruit Total Soluble Solids (\%) from Grafted and Non-Grafted Watermelon Plants Grown in Two Fields Over Two Years at Lane, OK

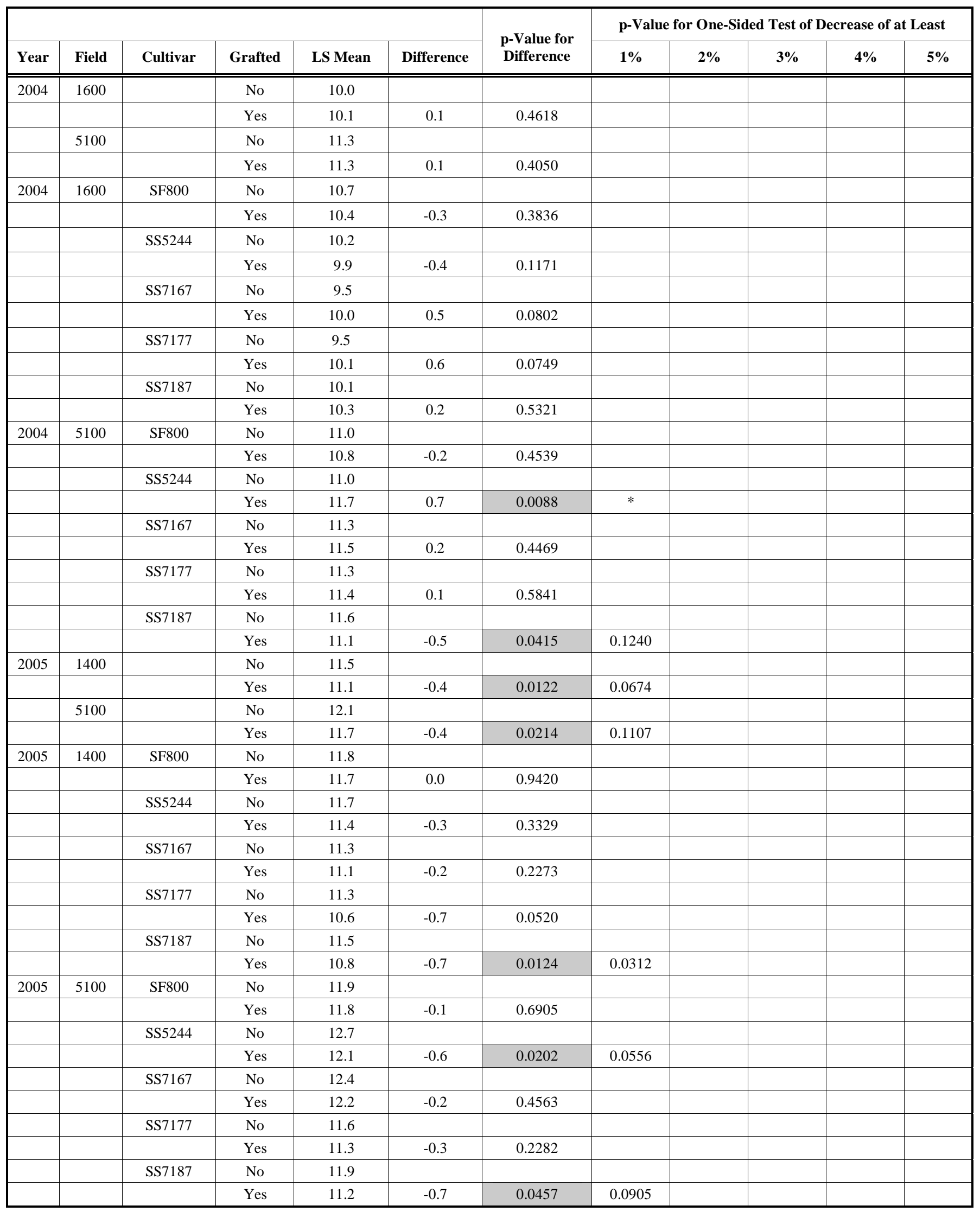

*Test was for decrease. This change was an increase.

Shaded block indicates statistical significance at $\mathrm{p} \leq 0.05$ level. 


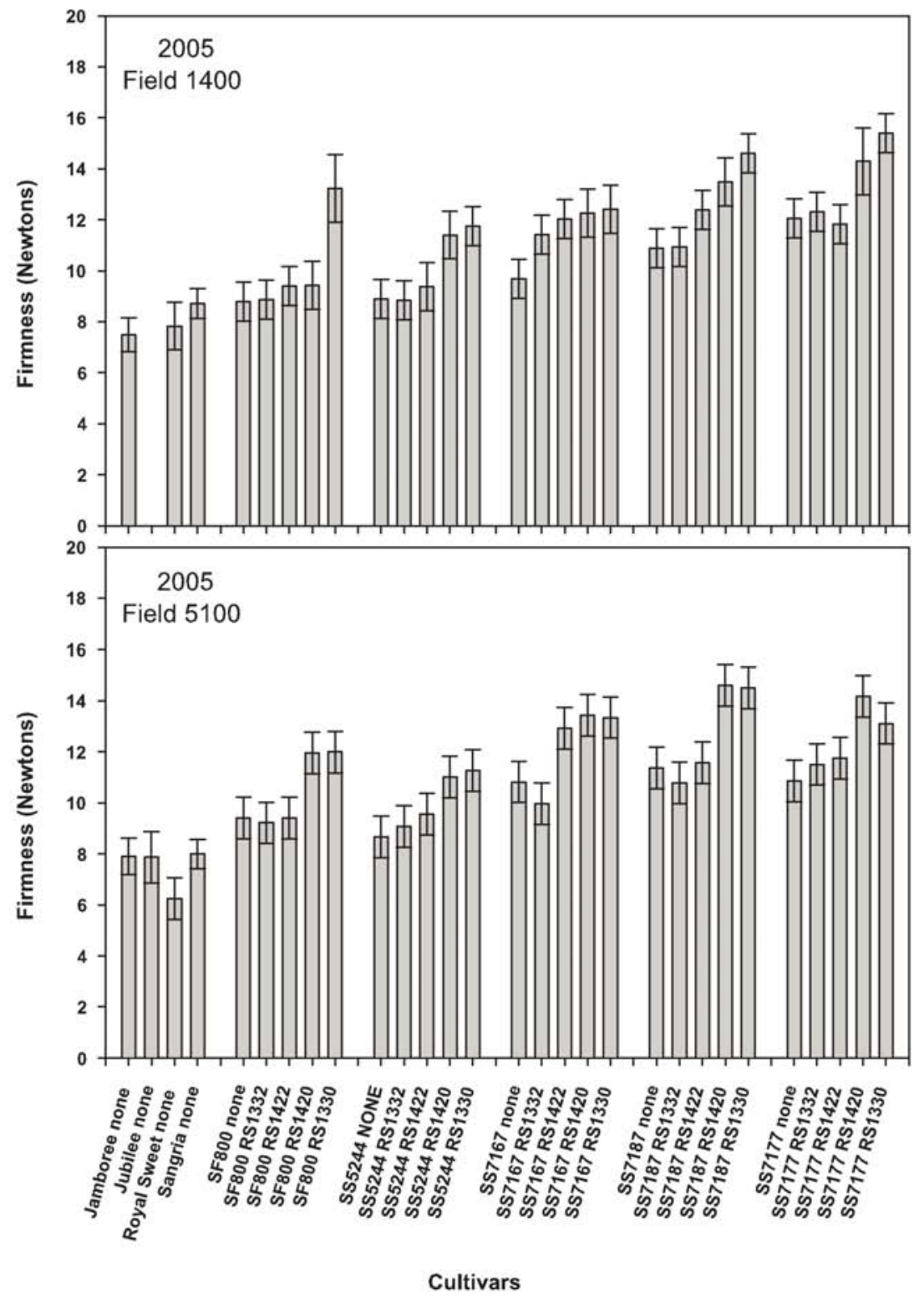

Fig. (4). Fruit firmness measurements from grafted and non-grafted watermelon plants in 2005. Method of measurement is described in Materials and Methods. Bars represent pooled standard errors at $\mathrm{p} \leq 0.05$.

to $8.8 \mathrm{~N}$ (Fig. 4, Appendix Tables $\mathbf{3}$ and $\mathbf{5}$ ). Rootstocks 'RS 1330' (C. maxima x C. moschata) and 'RS 1420' (C. ficifolia) produced fruit with the highest firmness values (Appendix Table 5). There were no differences in fruit firmness between grafted and non-grafted fruit in 'SF5244' and 'SS7167' (Appendix Table 3).

In field $\# 5100$ for crop year 2005, fruit firmness from non-grafted plants ranged from 11.4 to $6.2 \mathrm{~N}$ while the range of fruit firmness from grafted plants was 14.6 to $9.1 \mathrm{~N}$ (Fig. 4, Appendix Tables 3 and 5). Scions 'SF800,' 'SF5244,' 'SS7167,' 'SS7177' showed no significant differences between non-grafted and grafted rootstocks for fruit firmness (Appendix Table 3). With scion 'SS7187,' rootstocks 'RS 1330 ' and 'RS 1420' produced significantly greater fruit firmness than other rootstocks and non-grafted fruit. In both fields, there was a significant increase in fruit firmness due to grafting, although less than 5\% (Table 4).

\section{Lycopene}

In field \#1400 for crop year 2005, fruit from non-grafted plants ranged from 56.6 to $45.2 \mu \mathrm{g} / \mathrm{g}$ of tissue, whereas, fruit from grafted plants ranged from 69.1 to $47.1 \mu \mathrm{g} / \mathrm{g}$ of tissue (Fig. 5, Appendix Tables 3 and 5). Only in fruit of the nongrafted diploids was there a significant difference in lycopene content, where 'Sangria' $(53.2 \mu \mathrm{g} / \mathrm{g})$ had more lycopene than either 'Jamboree' $(47.5 \mu \mathrm{g} / \mathrm{g})$ or 'Royal Sweet' (45.2 $\mu \mathrm{g} / \mathrm{g}$ ) (Appendix Table 3).

In field \#5100, fruit from non-grafted plants ranged from 76.1 to $58.5 \mu \mathrm{g} / \mathrm{g}$ of tissue, whereas, fruit from grafted plants ranged from 78.9 to $61.3 \mu \mathrm{g} / \mathrm{g}$ of tissue (Fig. 5, Appendix Tables 3 and 5). There were no significant differences in lycopene content among fruit of grafted plants or fruit from the non-grafted diploids, except for scion 'SF5244' when grafted onto 'RS 1330' or 'RS 1420' where it produced 


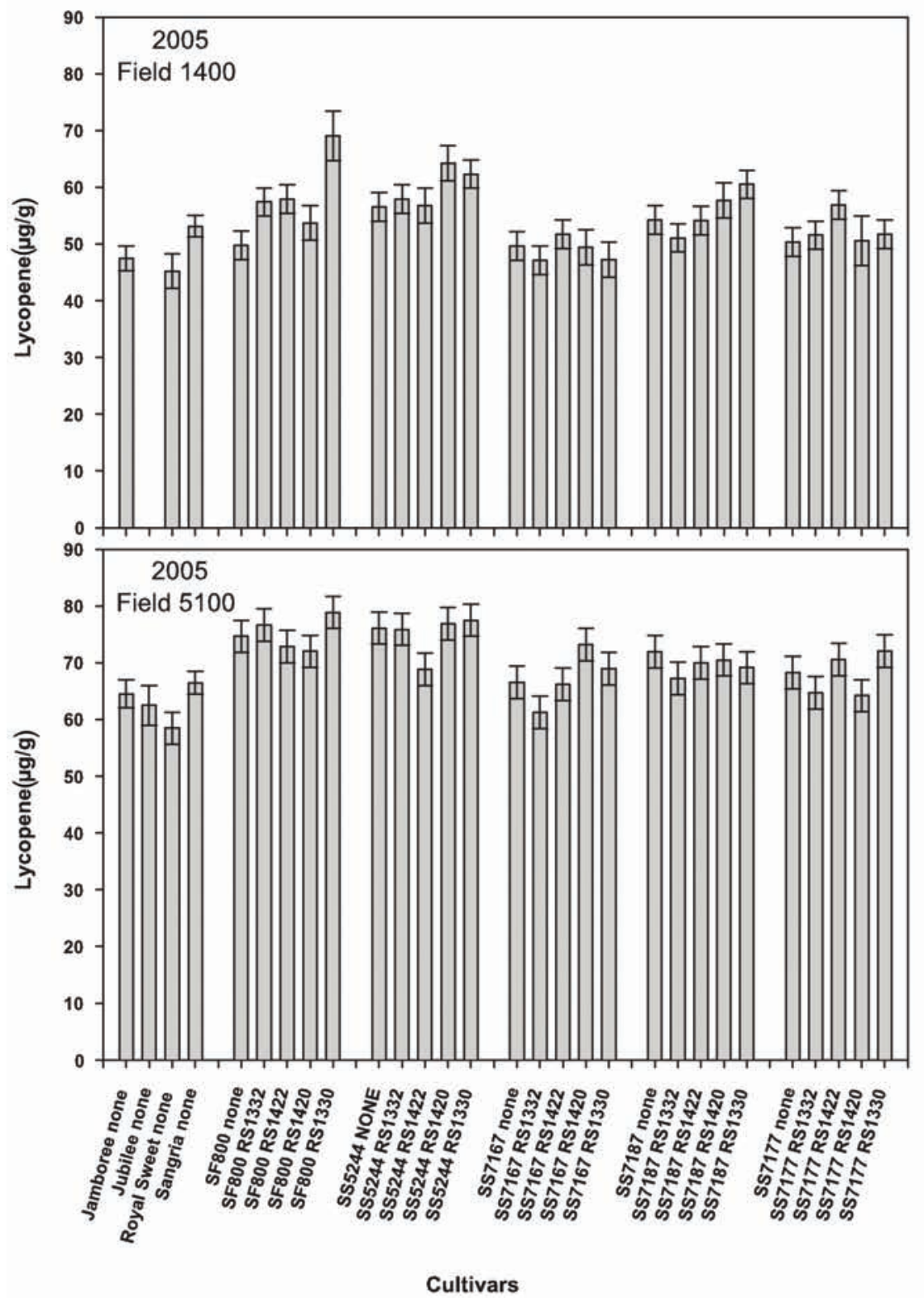

Fig. (5). Lycopene content ( $\mu \mathrm{g} / \mathrm{g}$ tissue) in watermelon fruit from grafted and non-grafted plants in 2005. Method of measurement is described in Materials and Methods. Bars represent pooled standard errors at $\mathrm{p} \leq 0.05$.

higher lycopene. In no case, did grafting to these rootstocks decrease lycopene. Further, there was never a change in lycopene content by as much as $5 \%$ in either field (Table $\mathbf{5}$ ).

\section{Total Soluble Solids}

In field \#1400 during crop year 2005, TSS in fruit of non-grafted plants ranged from 11.4 to $11.3 \%$, whereas, fruit of grafted plants ranged from 12.0 to $9.9 \%$ (Fig. 6, Appendix Tables 3 and 5). Even where there were statistically significant differences in TSS these differences were less than $2 \%$ (Table 6).

In field \#5100 for crop year 2005, TSS in fruit from nongrafted plants ranged from 12.74 to $11.2 \%$, whereas, fruit of grafted plants ranged from 12.6 to $10.9 \%$ (Fig. 6, Appendix Tables 3 and 5). Similar to the situation in field \#1400, there was never as much as a $2 \%$ change in TSS in field \#5100 (Table 6).

\section{DISCUSSION}

This study demonstrates that the only fruit quality trait consistently affected by grafting watermelon scion onto various rootstocks was fruit firmness. However, fruit firmness was also strongly influenced by year-to-year interactions with field and climatic conditions. As a rule, fruit of scions grafted onto 'RS 1330' (C. maxima x C. moschata) or 'RS 1420' (C. ficifolia) exhibited higher fruit firmness values when compared to the other $C$. maxima x $C$. moschata hybrids or L. siceraria rootstocks used in this study. Although grafting increased fruit firmness by as much as $25 \%$ in some cases, we also observed field and year effects. Liu et al. [15] reported no difference in fruit 'texture' (firmness?) when diploid watermelons were grafted onto five different rootstocks consisting of $L$. siceraria or C. ficifolia. However, Yamasaki et al. [34] reported a significant increase in fruit 


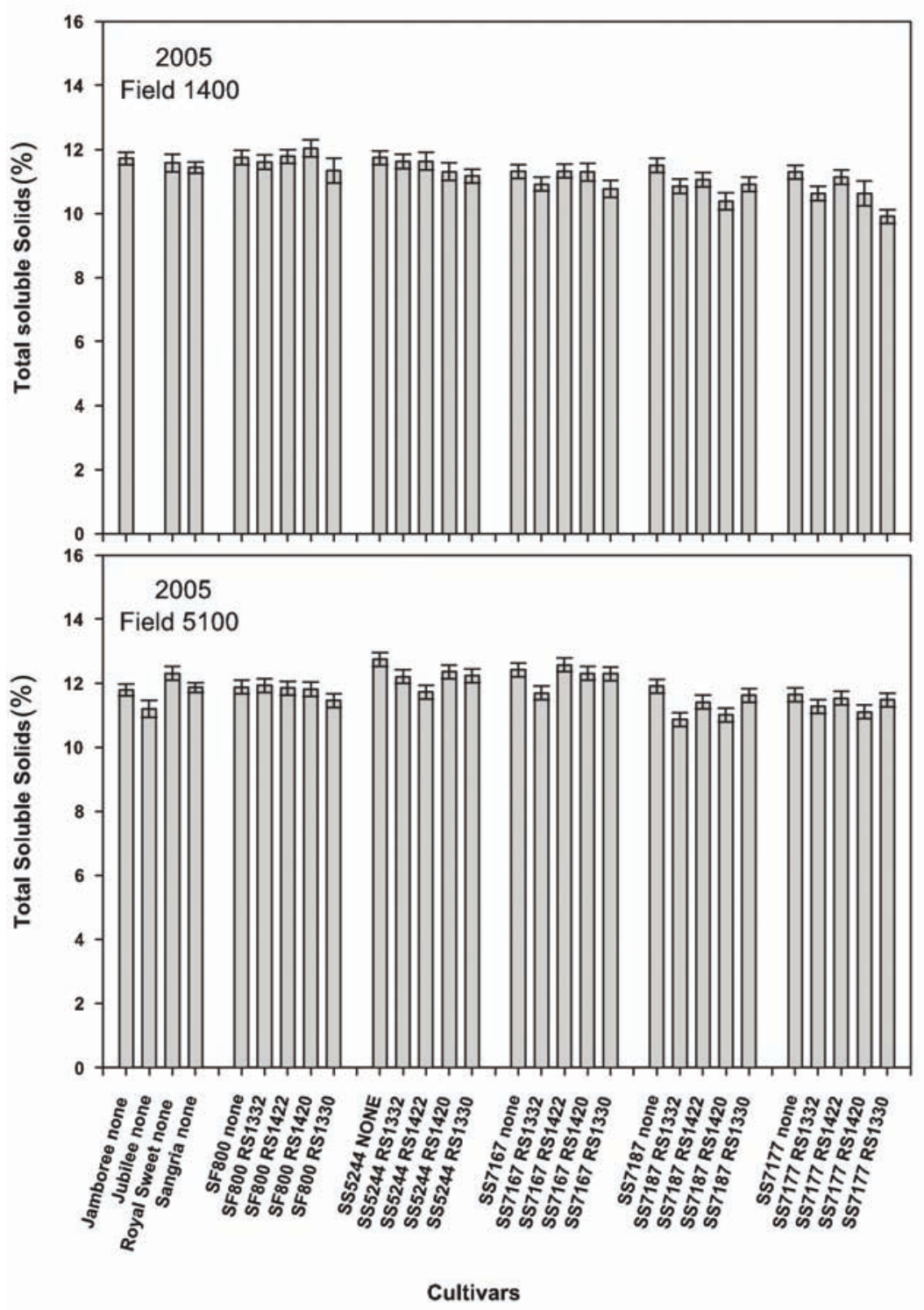

Fig. (6). Total soluble solids in watermelon fruit from grafted and non-grafted plants in 2004. Method of measurement is described in Materials and Methods. Bars represent pooled standard errors at $\mathrm{p} \leq 0.05$.

firmness when watermelon scion was grafted onto $C$. maxima x $C$. moschata $(3.17 \mathrm{~N})$ but not when grafted onto $L$. siceraria $(2.79 \mathrm{~N})$. Yetisir et al. [16] measured a significant increase in fruit firmness when 'Crimson Tide' watermelon (diploid) was grafted onto $C$. moschata $(12.63 \mathrm{~N})$ or $C$. maxima $(11.62 \mathrm{~N})$ as compared to the non-grafted control $(6.85 \mathrm{~N})$. In contrast, he found no increase in fruit firmness when 'Crimson Tide' was grafted onto various L. siceraria or Cucurbita sp. hybrids. The present study clearly demonstrates that the non-grafted triploid watermelons ('SS7167,' 'SS7177,' and 'SS7187') were inherently firmer (10-25\%) than the diploids ('Jamboree,' 'Jubilee,' 'Royal Sweet,' 'Sangria,' and 'SF800').

From a nutraceutical standpoint, lycopene may be the most important component of watermelon fruit. In the present study, lycopene ranged between 43.6 to $78.5 \mu \mathrm{g} / \mathrm{g}$ of tissue. These values are consistent with those reported by Perkins-Veazie et al. [32], in which watermelon cultivars can have a wide range of values for lycopene content ranging from a low of $<50 \mu \mathrm{g} / \mathrm{g}$ to a very high $>90 \mu \mathrm{g} / \mathrm{g}$ of tissue. Although grafting did produce a statistically significant increase in lycopene content in a few cases, the increase was always less than $5 \%$. Contrary to our results, Proietti et al. [35] noted a $40 \%$ increase in lycopene content in a miniwatermelon grafted onto a C. moschata x C. maxima rootstock. Liu et al. [15] grafted seeded watermelon onto five different rootstocks of $L$. siceraria or $C$. ficifolia and noted higher amino acid and carotene content in fruit of grafted vs. non-grafted watermelon. As noted in fruit firmness, lycopene content of watermelon exhibited both field and year effects in this study and demonstrates that environment may provoke a greater influence on lycopene than grafting.

Sugar content appears to be one of the most important characteristics of a good-quality watermelon, based on the fruit quality indices routinely measured by scientists. Previous research has generally shown that grafting has little or no 
effect on TSS content in watermelon fruit [13, 36]. Miguel et al. [14] noted no significant effect on TSS of fruit when grafting watermelon onto $C$. moschata, $C$. maxima x $C$. moschata, or $L$. siceraria rootstocks under field conditions. However, grafting the same watermelon onto C. maxima $\mathrm{x}$ C. moschata under greenhouse conditions decreased TSS in the fruit suggesting a possible interaction with environment on fruit quality [12]. Yetisir and Sari [19] also noted that there is a rootstock effect on TSS in the fruit. Although some researchers [10, 16, 34, 37] have reported a significant reduction in TSS in fruit of grafted watermelon, the decrease is rather small and the TSS levels are generally above $10 \%$, which is the value required to achieve \#1 grade by the United States Standards for Grades of Watermelons [38]. Liu et al. [15] reported no difference in taste or fruit maturity when grafting watermelon onto L. siceraria or C. ficifolia. Yamasaki et al. [34] noted inferior fruit flavor when watermelon was grafted onto $C$. maxima x $C$. moschata but not $L$. siceraria. Although no taste panel was used in the present study, anecdotal responses by consumer tasting rated the fruit flavor of grafted watermelon equal to or superior to non-grafted watermelon (data not presented). We did observe that fruit maturity of grafted watermelon was delayed about 5 to 7 days beyond the non-grafterd counterpart which could account for reduced TSS and off flavor as noted in some grafting studies. Mondal et al. [39] also noted late maturation of watermelon fruit using L. leucantha, C. moschata, and $C$. maxima $\mathrm{x} C$. moschata as the rootstock. The observed delay in fruit maturity may be explained by Salam et al. [40] who recorded a 4-day delay in the appearance of first female flowers when watermelon was grafted onto L. siceraria.

Historically, the selection of rootstocks has been toward resistance to disease and/or environmental stresses $[5,8]$. $L$. siceraria has been frequently used as a rootstock for watermelon, but the incidence of Fusarium wilt caused by $F$. oxysporum $\mathrm{f}$. sp. lagenariae has dramatically increased in major watermelon production regions in Japan and Korea [5, 41]. As a result, there has been an effort to find other rootstocks that are resistant to Fusarium wilt. Each of the rootstocks used in this study were highly resistant/tolerant to race 2 of $F$. oxysporum f. sp. niveum and Verticillium dahliae as determined by greenhouse inoculation of the rootstocks alone (unpublished data). Although some studies have concluded that Cucurbita sp. rootstocks may produce inferior watermelon fruit quality [5, 42], our studies do not support that conclusion.

\section{CONCLUSION}

To our knowledge, this study represents the most comprehensive evaluation carried out to date on the effects of grafted watermelon with respect to fruit firmness and lycopene content. Although environment can have a major influence on fruit quality attributes, rootstock selection appears to be equally important to achieving the desired outcome.
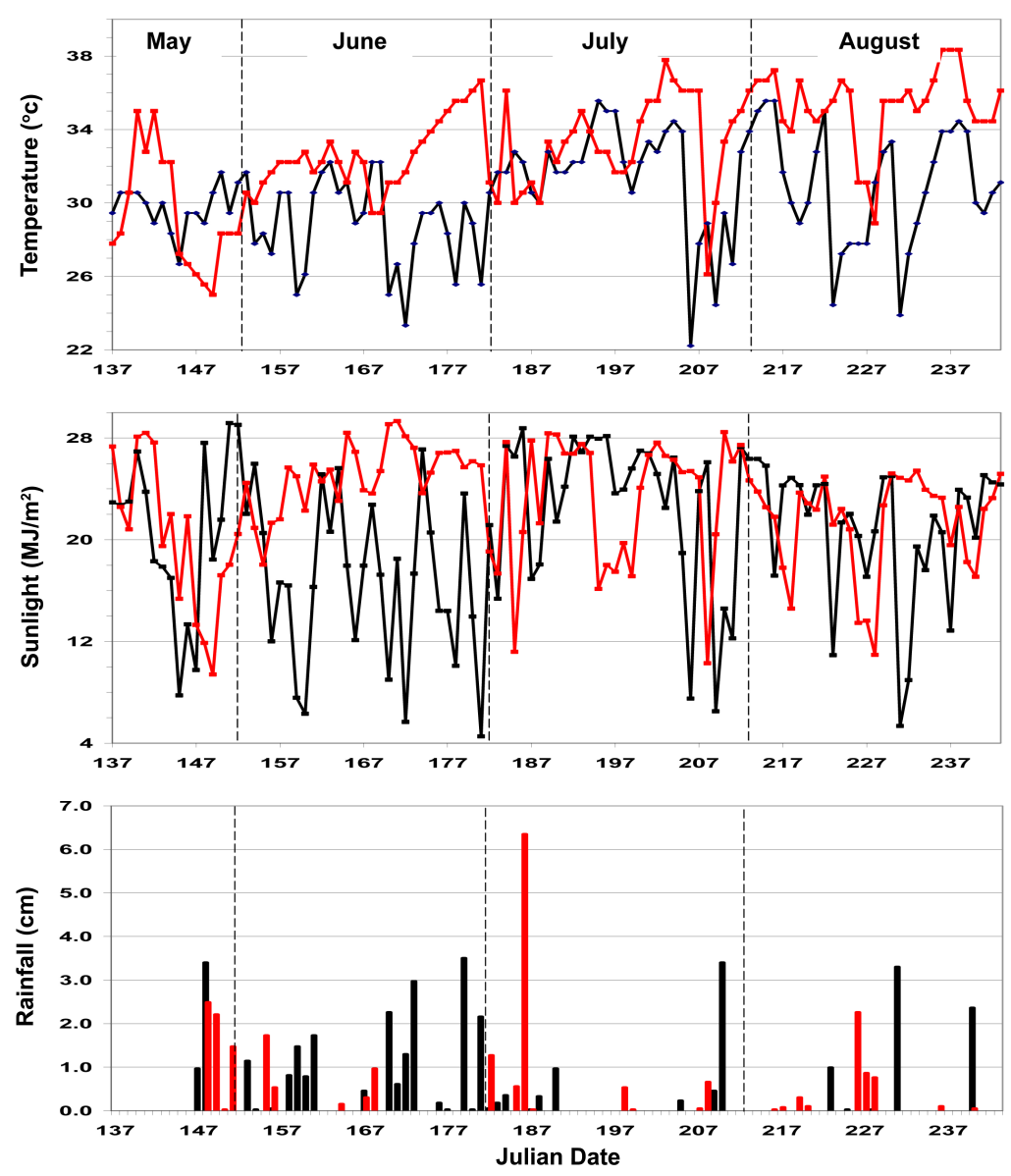

Appendix Fig. (1). Environmental parameters (temperature, sunlight, and rainfall) measured during the watermelon growing seasons 2004 (black) and 2005 (red). 
Appendix Table 1. Environmental Data for Different Fields in 2004 and 2005

\begin{tabular}{|c|c|c|c|c|c|c|c|}
\hline Crop Year & Field \# & $\begin{array}{l}\text { Planting } \\
\text { Date }\end{array}$ & $\begin{array}{c}\text { Time Inter- } \\
\text { val }\end{array}$ & $\operatorname{Max} \operatorname{Temp}\left({ }^{\circ} \mathrm{C}\right)$ & Min Temp $\left({ }^{\circ} \mathbf{C}\right)$ & $\begin{array}{c}\text { Mean Solar } \\
\text { Radiation }\end{array}$ & Rainfall \\
\hline & & & (da) & (Mean) & (Mean) & $\mathbf{M J} / \mathbf{m}^{2}$ & $(\mathbf{c m})$ \\
\hline \multirow[t]{3}{*}{2004} & 1600 & 17-May & $0-30$ & 29.6 & 19.5 & 19.2 & 10.4 \\
\hline & & & $30-60$ & 30.3 & 20.8 & 20.1 & 15.4 \\
\hline & & & $60-90$ & 30.9 & 18.6 & 21.8 & 5.1 \\
\hline \multirow[t]{3}{*}{2004} & 5100 & 24-May & $0-30$ & 29.1 & 19.7 & 17.6 & 18.0 \\
\hline & & & $30-60$ & 31.4 & 20.5 & 22.3 & 7.8 \\
\hline & & & $60-90$ & 30.0 & 18.3 & 20.0 & 8.4 \\
\hline \multirow[t]{3}{*}{2005} & 1400 & 27-May & $0-30$ & 30.9 & 19.1 & 22.9 & 9.9 \\
\hline & & & $30-60$ & 33.8 & 21.2 & 23.7 & 8.8 \\
\hline & & & $60-90$ & 34.6 & 21.1 & 21.8 & 5.2 \\
\hline \multirow[t]{3}{*}{2005} & 5100 & 1-June & $0-30$ & 32.4 & 19.7 & 24.9 & 3.7 \\
\hline & & & $30-60$ & 33.1 & 20.9 & 23.0 & 9.5 \\
\hline & & & $60-90$ & 35.3 & 21.7 & 21.4 & 4.5 \\
\hline
\end{tabular}

Appendix Table 2. Fruit Quality Attribute Comparisons of Rootstock within Watermelon Cultivars Used as Scions in 2004

\begin{tabular}{|c|c|c|c|c|c|c|c|c|c|c|c|c|c|c|c|c|c|c|c|}
\hline \multirow{4}{*}{$\begin{array}{l}\text { Cultivar } \\
\text { Jamboree }\end{array}$} & \multirow{4}{*}{$\begin{array}{c}\text { Root Stock } \\
\text { none }\end{array}$} & \multicolumn{6}{|c|}{ Firmness (N) } & \multicolumn{6}{|c|}{ Lycopene ( $\mu \mathrm{g} / \mathrm{g})$} & \multicolumn{6}{|c|}{ Soluble Solids (\%) } \\
\hline & & \multicolumn{3}{|c|}{ Field 1600} & \multicolumn{3}{|c|}{ Field 5100} & \multicolumn{3}{|c|}{ Field 1600} & \multicolumn{3}{|c|}{ Field 5100} & \multicolumn{3}{|c|}{ Field 1600} & \multicolumn{3}{|c|}{ Field 5100} \\
\hline & & \multicolumn{2}{|c|}{ LS Mean } & \multirow{2}{*}{$\begin{array}{c}\begin{array}{l}\text { Std } \\
\text { Err }\end{array} \\
1.2\end{array}$} & \multicolumn{2}{|c|}{ LS Mean } & \multirow{2}{*}{$\begin{array}{c}\begin{array}{c}\text { Std } \\
\text { Err }\end{array} \\
0.7\end{array}$} & \multicolumn{2}{|c|}{ LS Mean } & \multirow{2}{*}{$\begin{array}{l}\begin{array}{c}\text { Std } \\
\text { Err }\end{array} \\
3.0\end{array}$} & \multicolumn{2}{|c|}{ LS Mean } & \multirow{2}{*}{$\begin{array}{l}\text { Std } \\
\text { Err }\end{array}$} & \multicolumn{2}{|c|}{ LS Mean } & \multirow{2}{*}{$\begin{array}{c}\begin{array}{c}\text { Std } \\
\text { Err }\end{array} \\
0.3\end{array}$} & \multicolumn{2}{|c|}{ LS Mean } & \multirow{2}{*}{$\begin{array}{l}\begin{array}{l}\text { Std } \\
\text { Err }\end{array} \\
0.2\end{array}$} \\
\hline & & 6.8 & $\mathrm{a}$ & & 5.9 & $\mathrm{~b}$ & & 46.5 & $\mathrm{~b}$ & & 59.5 & $\mathrm{a}$ & & 9.8 & $\mathrm{a}$ & & 10.5 & $\mathrm{~b}$ & \\
\hline Jubilee & none & 7.7 & a & 1.7 & 8.4 & $\mathrm{a}$ & 1.0 & 49.5 & $a b$ & 4.1 & 46.4 & $\mathrm{~b}$ & 2.8 & 10.0 & $\mathrm{a}$ & 0.4 & 9.7 & $\mathrm{c}$ & 0.3 \\
\hline $\begin{array}{l}\text { Royal } \\
\text { Sweet }\end{array}$ & none & 8.1 & $\mathrm{a}$ & 1.3 & 4.5 & $\mathrm{~b}$ & 0.9 & 45.2 & $\mathrm{~b}$ & 3.1 & 43.6 & $\mathrm{~b}$ & 2.5 & 10.0 & $\mathrm{a}$ & 0.3 & 10.7 & $a b$ & 0.2 \\
\hline Sangria & none & 7.6 & a & 1.4 & 8.0 & $\mathrm{a}$ & 0.6 & 59.0 & $\mathrm{a}$ & 3.5 & 59.2 & $\mathrm{a}$ & 1.9 & 10.5 & $\mathrm{a}$ & 0.3 & 11.1 & $\mathrm{a}$ & 0.2 \\
\hline SF800 & none & 8.1 & $\mathrm{~b}$ & 1.4 & 9.9 & $\mathrm{a}$ & 0.7 & 63.5 & $\mathrm{a}$ & 3.3 & 69.3 & $a b$ & 2.1 & 10.7 & $\mathrm{a}$ & 0.3 & 11.0 & $\mathrm{a}$ & 0.2 \\
\hline SF800 & RS1330 & 11.8 & $\mathrm{a}$ & 1.2 & 10.5 & $\mathrm{a}$ & 0.9 & 51.5 & $\mathrm{~b}$ & 3.0 & 75.0 & $\mathrm{ab}$ & 2.6 & 10.5 & $\mathrm{a}$ & 0.3 & 11.1 & $\mathrm{a}$ & 0.2 \\
\hline SF800 & RS1332 & 9.3 & $\mathrm{ab}$ & 1.7 & 8.4 & $\mathrm{a}$ & 0.7 & 64.8 & $\mathrm{a}$ & 4.1 & 65.2 & $\mathrm{~b}$ & 2.6 & 9.8 & $\mathrm{a}$ & 0.3 & 10.5 & $\mathrm{a}$ & 0.2 \\
\hline SF800 & RS1420 & 11.3 & $\mathrm{ab}$ & 1.4 & 10.8 & $\mathrm{a}$ & 0.8 & 65.7 & $\mathrm{a}$ & 3.3 & 78.5 & $\mathrm{a}$ & 2.6 & 10.6 & $\mathrm{a}$ & 0.3 & 11.0 & $\mathrm{a}$ & 0.2 \\
\hline SF800 & RS1421 & 10.1 & $a b$ & 1.4 & 9.4 & $\mathrm{a}$ & 0.9 & 60.1 & $a b$ & 3.5 & 74.0 & $a b$ & 2.5 & 10.6 & $\mathrm{a}$ & 0.3 & 10.9 & $\mathrm{a}$ & 0.2 \\
\hline SS5244 & none & 10.3 & $\mathrm{~b}$ & 1.0 & 7.0 & $\mathrm{~b}$ & 0.7 & 55.4 & $a b$ & 2.3 & 64.6 & $\mathrm{~b}$ & 2.1 & 10.2 & $\mathrm{a}$ & 0.2 & 11.0 & $\mathrm{~b}$ & 0.2 \\
\hline SS5244 & RS1330 & 13.0 & $a b$ & 0.9 & 11.6 & $\mathrm{a}$ & 0.7 & 61.6 & $\mathrm{a}$ & 2.2 & 74.4 & $\mathrm{a}$ & 2.0 & 10.0 & $a b$ & 0.2 & 11.9 & $\mathrm{a}$ & 0.2 \\
\hline SS5244 & RS1332 & 11.3 & $a b$ & 1.5 & 10.7 & $\mathrm{a}$ & 0.8 & 65.6 & $\mathrm{a}$ & 3.8 & 64.2 & $\mathrm{~b}$ & 2.2 & 9.9 & $a b$ & 0.3 & 10.8 & $\mathrm{~b}$ & 0.2 \\
\hline SS5244 & RS1420 & 15.2 & $\mathrm{a}$ & 1.1 & 12.9 & $\mathrm{a}$ & 0.7 & 50.4 & $\mathrm{~b}$ & 2.8 & 74.1 & $\mathrm{a}$ & 2.0 & 9.4 & $\mathrm{~b}$ & 0.3 & 11.9 & $\mathrm{a}$ & 0.2 \\
\hline SS5244 & RS1421 & 9.8 & $\mathrm{~b}$ & 1.8 & 10.8 & $\mathrm{a}$ & 0.7 & 63.2 & $a b$ & 4.4 & 75.2 & $\mathrm{a}$ & 2.0 & 10.4 & $a b$ & 0.4 & 12.1 & $\mathrm{a}$ & 0.2 \\
\hline SS7167 & none & 13.3 & $\mathrm{bc}$ & 1.1 & 10.1 & $\mathrm{c}$ & 0.7 & 52.7 & $\mathrm{a}$ & 2.6 & 64.2 & $a b$ & 2.0 & 9.5 & $\mathrm{a}$ & 0.2 & 11.3 & $a b$ & 0.2 \\
\hline SS7167 & RS1330 & 17.8 & $a b$ & 0.8 & 13.7 & $a b$ & 0.7 & 51.9 & $\mathrm{a}$ & 1.9 & 66.2 & $a b$ & 2.0 & 9.8 & $\mathrm{a}$ & 0.2 & 11.7 & $a b$ & 0.2 \\
\hline SS7167 & RS1332 & 16.4 & $a b c$ & 1.0 & 13.0 & $a b$ & 0.7 & 58.1 & $\mathrm{a}$ & 2.4 & 64.2 & $a b$ & 2.1 & 9.9 & $\mathrm{a}$ & 0.2 & 11.3 & $a b$ & 0.2 \\
\hline
\end{tabular}


(Appendix Table 2). Contd.....

\begin{tabular}{|c|c|c|c|c|c|c|c|c|c|c|c|c|c|c|c|c|c|c|c|}
\hline SS7167 & RS1420 & 18.4 & $\mathrm{a}$ & 1.0 & 15.1 & $\mathrm{a}$ & 0.8 & 51.3 & $\mathrm{a}$ & 2.4 & 62.0 & $\mathrm{~b}$ & 2.3 & 9.9 & $\mathrm{a}$ & 0.2 & 11.1 & $\mathrm{~b}$ & 0.2 \\
\hline SS7167 & RS1421 & 12.1 & $\mathrm{c}$ & 0.8 & 11.3 & $\mathrm{bc}$ & 0.7 & 52.6 & $\mathrm{a}$ & 1.9 & 71.9 & $\mathrm{a}$ & 2.1 & 10.2 & $\mathrm{a}$ & 0.2 & 11.9 & $\mathrm{a}$ & 0.2 \\
\hline SS7177 & none & 13.9 & $\mathrm{~b}$ & 1.2 & 10.1 & $\mathrm{~b}$ & 0.6 & 54.2 & $\mathrm{a}$ & 2.9 & 62.0 & $\mathrm{c}$ & 1.7 & 9.4 & $\mathrm{a}$ & 0.3 & 11.3 & $\mathrm{a}$ & 0.2 \\
\hline SS7177 & RS1330 & 19.0 & $\mathrm{a}$ & 0.9 & 15.0 & $\mathrm{a}$ & 0.7 & 53.4 & $\mathrm{a}$ & 2.1 & 69.8 & $\mathrm{ab}$ & 2.0 & 10.4 & $\mathrm{a}$ & 0.2 & 11.5 & $\mathrm{a}$ & 0.2 \\
\hline SS7177 & RS1332 & 14.2 & $\mathrm{ab}$ & 1.5 & 13.7 & $\mathrm{a}$ & 0.7 & 54.6 & $\mathrm{a}$ & 3.8 & 65.6 & $\mathrm{abc}$ & 2.1 & 9.6 & $\mathrm{a}$ & 0.3 & 11.3 & $\mathrm{a}$ & 0.2 \\
\hline SS7177 & RS1420 & 18.9 & $\mathrm{a}$ & 1.0 & 16.3 & $\mathrm{a}$ & 0.7 & 59.1 & $\mathrm{a}$ & 2.4 & 72.6 & $\mathrm{a}$ & 2.0 & 10.2 & $\mathrm{a}$ & 0.2 & 11.5 & $\mathrm{a}$ & 0.2 \\
\hline SS7177 & RS1421 & 13.8 & $\mathrm{~b}$ & 1.4 & 15.0 & $\mathrm{a}$ & 0.7 & 49.8 & $\mathrm{a}$ & 3.3 & 63.3 & $\mathrm{bc}$ & 2.1 & 9.6 & $\mathrm{a}$ & 0.3 & 11.2 & $\mathrm{a}$ & 0.2 \\
\hline SS7187 & none & 14.5 & $\mathrm{a}$ & 1.1 & 10.7 & $\mathrm{c}$ & 0.7 & 58.2 & $\mathrm{a}$ & 2.6 & 59.3 & $\mathrm{a}$ & 2.0 & 10.1 & $\mathrm{a}$ & 0.2 & 11.6 & $\mathrm{a}$ & 0.2 \\
\hline SS7187 & RS1330 & 15.0 & $\mathrm{a}$ & 1.4 & 15.9 & $\mathrm{ab}$ & 0.7 & 64.1 & $\mathrm{a}$ & 3.5 & 67.3 & $\mathrm{a}$ & 2.0 & 9.8 & $\mathrm{a}$ & 0.3 & 11.4 & $\mathrm{a}$ & 0.2 \\
\hline SS7187 & RS1332 & 15.2 & $\mathrm{a}$ & 1.0 & 13.9 & $\mathrm{~b}$ & 0.7 & 56.1 & $\mathrm{a}$ & 2.5 & 60.7 & $\mathrm{a}$ & 2.0 & 10.5 & $\mathrm{a}$ & 0.2 & 11.0 & $\mathrm{a}$ & 0.2 \\
\hline SS7187 & RS1420 & $\mathrm{NT}$ & & & 19.2 & $\mathrm{a}$ & 1.2 & $\mathrm{NT}$ & & & 59.9 & $\mathrm{a}$ & 3.5 & $\mathrm{NT}$ & & & 10.6 & $\mathrm{a}$ & 0.3 \\
\hline SS7187 & RS1421 & 12.7 & $\mathrm{a}$ & 1.8 & 14.4 & $\mathrm{~b}$ & 0.7 & 65.1 & $\mathrm{a}$ & 4.4 & 61.1 & $\mathrm{a}$ & 2.0 & 10.3 & $\mathrm{a}$ & 0.4 & 11.2 & $\mathrm{a}$ & 0.2 \\
\hline
\end{tabular}

Values in Table are least square means with pooled standard errors within cultivar groupings. Means followed by same letters within a cultivar group within a column are not significantly different at $\mathrm{P} \leq 0.05$ using Tukey's adjusted means comparison.

NT: not tested.

Appendix Table 3. Fruit Quality Attribute Comparisons of Rootstock within Watermelon Cultivars Used as Scions in 2005

\begin{tabular}{|c|c|c|c|c|c|c|c|c|c|c|c|c|c|c|c|c|c|c|c|}
\hline \multirow{4}{*}{$\begin{array}{l}\text { Cultivar } \\
\text { Jamboree }\end{array}$} & \multirow{4}{*}{ 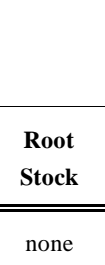 } & \multicolumn{6}{|c|}{ Firmness (N) } & \multicolumn{6}{|c|}{ Lycopene $(\mu \mathrm{g} / \mathrm{g})$} & \multicolumn{6}{|c|}{ Soluble Solids (\%) } \\
\hline & & \multirow{2}{*}{\multicolumn{2}{|c|}{$\begin{array}{l}\text { Field } 1400 \\
\text { LS Mean }\end{array}$}} & \multirow{3}{*}{$\begin{array}{l}\begin{array}{c}\text { Std } \\
\text { Err }\end{array} \\
0.7\end{array}$} & \multicolumn{3}{|c|}{ Field 5100} & \multicolumn{3}{|c|}{ Field 1400} & \multicolumn{3}{|c|}{ Field 5100} & \multicolumn{3}{|c|}{ Field 1400} & \multicolumn{3}{|c|}{ Field 5100} \\
\hline & & & & & \multicolumn{2}{|c|}{ LS Mean } & \multirow{2}{*}{$\begin{array}{r}\text { Std } \\
\text { Err }\end{array}$} & \multicolumn{2}{|c|}{ LS Mean } & \multirow{2}{*}{$\begin{array}{r}\begin{array}{l}\text { Std } \\
\text { Err }\end{array} \\
2.2\end{array}$} & \multicolumn{2}{|c|}{ LS Mean } & \multirow{2}{*}{$\begin{array}{l}\text { Std } \\
\text { Err }\end{array}$} & \multicolumn{2}{|c|}{ LS Mean } & \multirow{2}{*}{$\begin{array}{r}\text { Std } \\
\text { Err }\end{array}$} & \multicolumn{2}{|c|}{ LS Mean } & \multirow{2}{*}{$\begin{array}{l}\text { Std } \\
\text { Err } \\
0.2\end{array}$} \\
\hline & & 7.5 & $\mathrm{a}$ & & 7.9 & $\mathrm{a}$ & & 47.5 & $\mathrm{~b}$ & & 64.5 & $\mathrm{a}$ & & 11.7 & $\mathrm{a}$ & & 11.8 & $a b$ & \\
\hline Jubilee & none & NT & & & 7.9 & $\mathrm{a}$ & 1.0 & NT & & & 62.5 & $\mathrm{a}$ & 3.5 & NT & & & 11.2 & $\mathrm{~b}$ & 0.3 \\
\hline RoyalSweet & none & 7.8 & $\mathrm{a}$ & 0.9 & 6.2 & $\mathrm{~b}$ & 0.8 & 45.2 & $\mathrm{~b}$ & 3.1 & 58.5 & $\mathrm{a}$ & 2.8 & 11.6 & $\mathrm{a}$ & 0.3 & 12.3 & a & 0.2 \\
\hline Sangria & none & 8.7 & $\mathrm{a}$ & 0.6 & 8.0 & $\mathrm{a}$ & 0.6 & 53.2 & a & 1.9 & 66.4 & $\mathrm{a}$ & 2.0 & 11.4 & $\mathrm{a}$ & 0.2 & 11.9 & $a b$ & 0.2 \\
\hline SF_800 & none & 8.8 & $\mathrm{~b}$ & 0.8 & 9.4 & $\mathrm{a}$ & 0.8 & 49.8 & a & 2.5 & 74.6 & $\mathrm{a}$ & 2.8 & 11.8 & $\mathrm{a}$ & 0.2 & 11.9 & a & 0.2 \\
\hline SF_800 & RS1330 & 13.2 & $\mathrm{a}$ & 1.3 & 12.0 & $\mathrm{a}$ & 0.8 & 69.1 & a & 4.4 & 78.9 & $\mathrm{a}$ & 2.8 & 11.3 & $\mathrm{a}$ & 0.4 & 11.5 & $\mathrm{a}$ & 0.2 \\
\hline SF_800 & RS1332 & 8.9 & $\mathrm{~b}$ & 0.8 & 9.2 & $\mathrm{a}$ & 0.8 & 57.4 & $\mathrm{a}$ & 2.5 & 76.6 & $\mathrm{a}$ & 2.8 & 11.6 & $\mathrm{a}$ & 0.2 & 11.9 & $\mathrm{a}$ & 0.2 \\
\hline SF_800 & RS1420 & 9.4 & $\mathrm{ab}$ & 0.9 & 11.9 & $\mathrm{a}$ & 0.8 & 53.7 & a & 3.1 & 72.0 & $\mathrm{a}$ & 2.8 & 12.0 & $\mathrm{a}$ & 0.3 & 11.8 & a & 0.2 \\
\hline SF_800 & RS1422 & 9.4 & $\mathrm{ab}$ & 0.8 & 9.4 & $\mathrm{a}$ & 0.8 & 57.9 & $\mathrm{a}$ & 2.5 & 72.8 & $\mathrm{a}$ & 2.8 & 11.8 & $\mathrm{a}$ & 0.2 & 11.8 & a & 0.2 \\
\hline SS5244 & none & 8.9 & $\mathrm{a}$ & 0.8 & 8.7 & $\mathrm{a}$ & 0.8 & 56.6 & $\mathrm{a}$ & 2.5 & 76.1 & $a b$ & 2.8 & 11.7 & $\mathrm{a}$ & 0.2 & 12.7 & a & 0.2 \\
\hline SS5244 & RS1330 & 11.7 & $\mathrm{a}$ & 0.8 & 11.3 & $\mathrm{a}$ & 0.8 & 62.4 & $\mathrm{a}$ & 2.5 & 77.5 & $\mathrm{a}$ & 2.8 & 11.2 & $\mathrm{a}$ & 0.2 & 12.2 & $a b$ & 0.2 \\
\hline SS5244 & RS1332 & 8.8 & $\mathrm{a}$ & 0.8 & 9.1 & $\mathrm{a}$ & 0.8 & 58.0 & $\mathrm{a}$ & 2.5 & 75.9 & $a b$ & 2.8 & 11.6 & $\mathrm{a}$ & 0.2 & 12.2 & $a b$ & 0.2 \\
\hline SS5244 & RS1420 & 11.4 & $\mathrm{a}$ & 0.9 & 11.0 & $\mathrm{a}$ & 0.8 & 64.2 & $\mathrm{a}$ & 3.1 & 76.8 & $a b$ & 2.8 & 11.3 & $\mathrm{a}$ & 0.3 & 12.4 & $a b$ & 0.2 \\
\hline SS5244 & RS1422 & 9.4 & $\mathrm{a}$ & 0.9 & 9.6 & $\mathrm{a}$ & 0.8 & 56.8 & $\mathrm{a}$ & 3.1 & 68.8 & $\mathrm{~b}$ & 2.8 & 11.6 & $\mathrm{a}$ & 0.3 & 11.7 & b & 0.2 \\
\hline SS7167 & none & 9.7 & $\mathrm{a}$ & 0.8 & 10.8 & $\mathrm{a}$ & 0.8 & 49.6 & $\mathrm{a}$ & 2.5 & 66.5 & $\mathrm{a}$ & 2.8 & 11.3 & $a b$ & 0.2 & 12.4 & $a b$ & 0.2 \\
\hline SS7167 & RS1330 & 12.4 & $\mathrm{a}$ & 0.9 & 13.3 & $\mathrm{a}$ & 0.8 & 47.3 & $\mathrm{a}$ & 3.1 & 69.0 & $\mathrm{a}$ & 2.8 & 10.8 & $\mathrm{~b}$ & 0.3 & 12.3 & $a b$ & 0.2 \\
\hline SS7167 & RS1332 & 11.4 & $\mathrm{a}$ & 0.8 & 10.0 & $\mathrm{a}$ & 0.8 & 47.1 & $\mathrm{a}$ & 2.5 & 61.3 & $\mathrm{a}$ & 2.8 & 10.9 & $a b$ & 0.2 & 11.7 & b & 0.2 \\
\hline SS7167 & RS1420 & 12.3 & $\mathrm{a}$ & 0.9 & 13.4 & $\mathrm{a}$ & 0.8 & 49.5 & $\mathrm{a}$ & 3.1 & 73.2 & $\mathrm{a}$ & 2.8 & 11.3 & $a b$ & 0.3 & 12.3 & $\mathrm{ab}$ & 0.2 \\
\hline SS7167 & RS1422 & 12.0 & $\mathrm{a}$ & 0.8 & 12.9 & $\mathrm{a}$ & 0.8 & 51.7 & $\mathrm{a}$ & 2.5 & 66.2 & $\mathrm{a}$ & 2.8 & 11.3 & $\mathrm{a}$ & 0.2 & 12.6 & $\mathrm{a}$ & 0.2 \\
\hline
\end{tabular}


(Appendix Table 3). Contd.....

\begin{tabular}{|l|c|c|c|c|c|c|c|c|c|c|c|c|c|c|c|c|c|c|c|}
\hline SS7177 & none & 12.1 & $\mathrm{~b}$ & 0.8 & 10.9 & $\mathrm{a}$ & 0.8 & 50.3 & $\mathrm{a}$ & 2.5 & 68.3 & $\mathrm{a}$ & 2.8 & 11.3 & $\mathrm{a}$ & 0.2 & 11.6 & $\mathrm{a}$ & 0.2 \\
\hline SS7177 & RS1330 & 15.4 & $\mathrm{a}$ & 0.8 & 13.1 & $\mathrm{a}$ & 0.8 & 51.7 & $\mathrm{a}$ & 2.5 & 72.1 & $\mathrm{a}$ & 2.8 & 9.9 & $\mathrm{~b}$ & 0.2 & 11.5 & $\mathrm{a}$ & 0.2 \\
\hline SS7177 & RS1332 & 12.3 & $\mathrm{ab}$ & 0.8 & 11.5 & $\mathrm{a}$ & 0.8 & 51.5 & $\mathrm{a}$ & 2.5 & 64.7 & $\mathrm{a}$ & 2.8 & 10.6 & $\mathrm{ab}$ & 0.2 & 11.3 & $\mathrm{a}$ & 0.2 \\
\hline SS7177 & RS1420 & 14.3 & $\mathrm{ab}$ & 1.3 & 14.2 & $\mathrm{a}$ & 0.8 & 50.6 & $\mathrm{a}$ & 4.4 & 64.2 & $\mathrm{a}$ & 2.8 & 10.6 & $\mathrm{ab}$ & 0.4 & 11.1 & $\mathrm{a}$ & 0.2 \\
\hline SS7177 & RS1422 & 11.8 & $\mathrm{~b}$ & 0.8 & 11.8 & $\mathrm{a}$ & 0.8 & 56.8 & $\mathrm{a}$ & 2.5 & 70.6 & $\mathrm{a}$ & 2.8 & 11.1 & $\mathrm{a}$ & 0.2 & 11.5 & $\mathrm{a}$ & 0.2 \\
\hline SS7187 & none & 10.9 & $\mathrm{~b}$ & 0.8 & 11.4 & $\mathrm{~b}$ & 0.8 & 54.2 & $\mathrm{a}$ & 2.5 & 71.9 & $\mathrm{a}$ & 2.8 & 11.5 & $\mathrm{a}$ & 0.2 & 11.9 & $\mathrm{a}$ & 0.2 \\
\hline SS7187 & RS1330 & 14.6 & $\mathrm{a}$ & 0.8 & 14.5 & $\mathrm{a}$ & 0.8 & 60.5 & $\mathrm{a}$ & 2.5 & 69.2 & $\mathrm{a}$ & 2.8 & 10.9 & $\mathrm{ab}$ & 0.2 & 11.6 & $\mathrm{a}$ & 0.2 \\
\hline SS7187 & RS1332 & 10.9 & $\mathrm{~b}$ & 0.8 & 10.8 & $\mathrm{~b}$ & 0.8 & 51.1 & $\mathrm{a}$ & 2.5 & 67.3 & $\mathrm{a}$ & 2.8 & 10.8 & $\mathrm{ab}$ & 0.2 & 10.9 & $\mathrm{a}$ & 0.2 \\
\hline SS7187 & RS1420 & 13.5 & $\mathrm{ab}$ & 0.9 & 14.6 & $\mathrm{a}$ & 0.8 & 57.7 & $\mathrm{a}$ & 3.1 & 70.5 & $\mathrm{a}$ & 2.8 & 10.4 & $\mathrm{~b}$ & 0.3 & 11.0 & $\mathrm{a}$ & 0.2 \\
\hline SS7187 & RS1422 & 12.4 & $\mathrm{ab}$ & 0.8 & 11.6 & $\mathrm{ab}$ & 0.8 & 54.1 & $\mathrm{a}$ & 2.5 & 70.0 & $\mathrm{a}$ & 2.8 & 11.1 & $\mathrm{ab}$ & 0.2 & 11.4 & $\mathrm{a}$ & 0.2 \\
\hline
\end{tabular}

Values in Table are least square means with pooled standard errors within cultivar groupings. Means followed by same letters within a cultivar group within a column are not significantly different at $\mathrm{P} \leq 0.05$ using Tukey's adjusted means comparison.

NT: not tested.

Appendix Table 4. Fruit Quality Attribute Comparisons of Watermelon Cultivars Used as Scions within Rootstocks in 2004

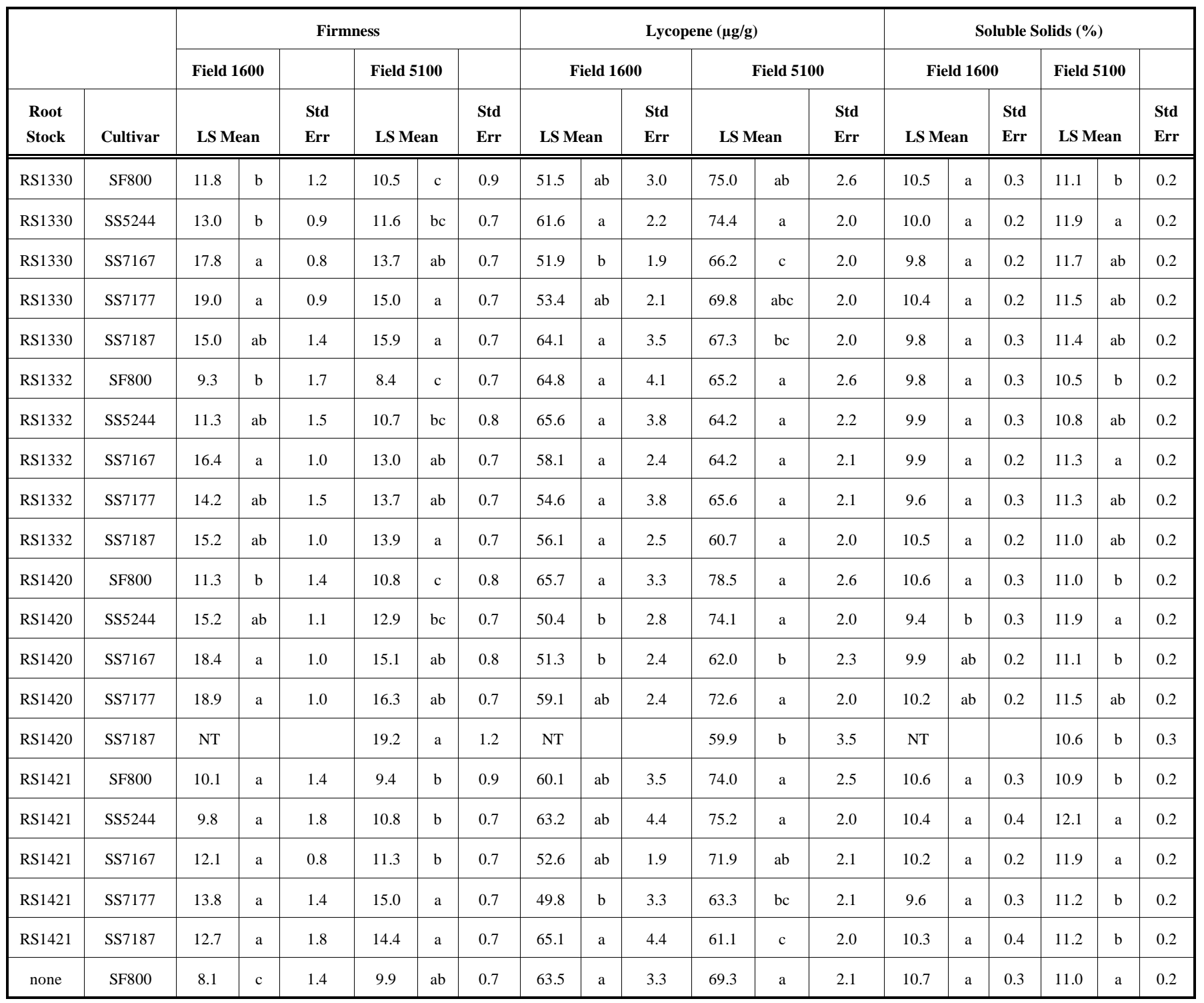


(Appendix Table 4). Contd.....

\begin{tabular}{|c|c|c|c|c|c|c|c|c|c|c|c|c|c|c|c|c|c|c|c|}
\hline none & SS5244 & 10.3 & $\mathrm{bc}$ & 1.0 & 7.0 & $\mathrm{~b}$ & 0.7 & 55.4 & $\mathrm{a}$ & 2.3 & 64.6 & $\mathrm{ab}$ & 2.1 & 10.2 & $\mathrm{a}$ & 0.2 & 11.0 & $\mathrm{a}$ & 0.2 \\
\hline none & SS7167 & 13.3 & $a b$ & 1.1 & 10.1 & $\mathrm{a}$ & 0.7 & 52.7 & $\mathrm{a}$ & 2.6 & 64.2 & $a b$ & 2.0 & 9.5 & $\mathrm{a}$ & 0.2 & 11.3 & $\mathrm{a}$ & 0.2 \\
\hline none & SS7177 & 13.9 & $a b$ & 1.2 & 10.1 & $\mathrm{a}$ & 0.6 & 54.2 & $\mathrm{a}$ & 2.9 & 62.0 & $a b$ & 1.7 & 9.4 & $\mathrm{a}$ & 0.3 & 11.3 & $\mathrm{a}$ & 0.2 \\
\hline none & SS7187 & 14.5 & $\mathrm{a}$ & 1.1 & 10.7 & $\mathrm{a}$ & 0.7 & 58.2 & $\mathrm{a}$ & 2.6 & 59.3 & $\mathrm{~b}$ & 2.0 & 10.1 & $\mathrm{a}$ & 0.2 & 11.6 & $\mathrm{a}$ & 0.2 \\
\hline none & Jamboree & 6.8 & $\mathrm{a}$ & 1.2 & 5.9 & $\mathrm{~b}$ & 0.7 & 46.5 & $\mathrm{~b}$ & 3.0 & 59.5 & $\mathrm{a}$ & 2.5 & 9.8 & $\mathrm{a}$ & 0.3 & 10.5 & $\mathrm{~b}$ & 0.2 \\
\hline none & Jubilee & 7.7 & $\mathrm{a}$ & 1.7 & 8.4 & $\mathrm{a}$ & 1.0 & 49.5 & $a b$ & 4.1 & 46.4 & $\mathrm{~b}$ & 2.8 & 10.0 & $\mathrm{a}$ & 0.4 & 9.7 & $\mathrm{c}$ & 0.3 \\
\hline none & $\begin{array}{l}\text { Royal } \\
\text { Sweet }\end{array}$ & 8.1 & $\mathrm{a}$ & 1.3 & 4.5 & $\mathrm{~b}$ & 0.9 & 45.2 & $\mathrm{~b}$ & 3.1 & 43.6 & $\mathrm{~b}$ & 2.5 & 10.0 & $\mathrm{a}$ & 0.3 & 10.7 & $a b$ & 0.2 \\
\hline none & Sangria & 7.6 & $\mathrm{a}$ & 1.4 & 8.0 & $\mathrm{a}$ & 0.6 & 59.0 & $\mathrm{a}$ & 3.5 & 59.2 & $\mathrm{a}$ & 1.9 & 10.5 & $\mathrm{a}$ & 0.3 & 11.1 & $\mathrm{a}$ & 0.2 \\
\hline
\end{tabular}

Values in the Table are least square means with pooled standard errors in rootstock groupings. Means followed by same letters within a cultivar group within a column are not significantly different at $\mathrm{P} \leq 0.05$ using Tukey's adjusted means comparison.

NT: not tested.

\section{Appendix Table 5. Fruit Quality Attribute Comparisons of Watermelon Cultivars Used as Scions within Rootstocks in 2005}

\begin{tabular}{|c|c|c|c|c|c|c|c|c|c|c|c|c|c|c|c|c|c|c|c|}
\hline \multirow{4}{*}{$\begin{array}{c}\begin{array}{c}\text { Root } \\
\text { Stock }\end{array} \\
\text { RS1330 }\end{array}$} & \multirow{4}{*}{$\begin{array}{c}\text { Cultivar } \\
\text { SF800 }\end{array}$} & \multicolumn{6}{|c|}{ Firmness (N) } & \multicolumn{6}{|c|}{ Lycopene ( $\mu \mathrm{g} / \mathrm{g})$} & \multicolumn{6}{|c|}{ Sugar $(\%)$} \\
\hline & & \multicolumn{3}{|c|}{ Field 1400} & \multicolumn{3}{|c|}{ Field 5100} & \multicolumn{3}{|c|}{ Field 1400} & \multicolumn{3}{|c|}{ Field 5100} & \multicolumn{3}{|c|}{ Field 1400} & \multicolumn{3}{|c|}{ Field 5100} \\
\hline & & \multicolumn{2}{|c|}{ LS Mean } & \multirow{2}{*}{$\begin{array}{l}\text { Std } \\
\text { Err }\end{array}$} & \multicolumn{2}{|c|}{ LS Mean } & \multirow{2}{*}{$\begin{array}{c}\text { Std } \\
\text { Err }\end{array}$} & \multicolumn{2}{|c|}{ LS Mean } & \multirow{2}{*}{$\begin{array}{l}\text { Std } \\
\text { Err }\end{array}$} & \multicolumn{2}{|c|}{ LS Mean } & \multirow{2}{*}{$\begin{array}{l}\text { Std } \\
\text { Err }\end{array}$} & \multicolumn{2}{|c|}{ LS Mean } & \multirow{2}{*}{$\begin{array}{c}\begin{array}{c}\text { Std } \\
\text { Err }\end{array} \\
0.4\end{array}$} & \multicolumn{2}{|c|}{ LS Mean } & \multirow{2}{*}{$\begin{array}{r}\text { Std } \\
\text { Err }\end{array}$} \\
\hline & & 13.2 & $\mathrm{a}$ & & 12.0 & $\mathrm{a}$ & & 69.1 & $\mathrm{a}$ & & 78.9 & $\mathrm{a}$ & & 11.3 & $a b$ & & 11.5 & $\mathrm{a}$ & \\
\hline RS1330 & SS5244 & 11.7 & $\mathrm{a}$ & 0.8 & 11.3 & $\mathrm{a}$ & 0.8 & 62.4 & $\mathrm{a}$ & 2.5 & 77.5 & $\mathrm{a}$ & 2.8 & 11.2 & $\mathrm{a}$ & 0.2 & 12.2 & $\mathrm{a}$ & 0.2 \\
\hline RS1330 & SS7167 & 12.4 & $\mathrm{a}$ & 0.9 & 13.3 & a & 0.8 & 47.3 & c & 3.1 & 69.0 & $\mathrm{a}$ & 2.8 & 10.8 & $\mathrm{ab}$ & 0.3 & 12.3 & $\mathrm{a}$ & 0.2 \\
\hline RS1330 & SS7177 & 15.4 & $\mathrm{a}$ & 0.8 & 13.1 & $\mathrm{a}$ & 0.8 & 51.7 & $\mathrm{bc}$ & 2.5 & 72.1 & $\mathrm{a}$ & 2.8 & 9.9 & $\mathrm{~b}$ & 0.2 & 11.5 & $\mathrm{a}$ & 0.2 \\
\hline RS1330 & SS7187 & 14.6 & $\mathrm{a}$ & 0.8 & 14.5 & $\mathrm{a}$ & 0.8 & 60.5 & $\mathrm{ab}$ & 2.5 & 69.2 & $\mathrm{a}$ & 2.8 & 10.9 & $\mathrm{ab}$ & 0.2 & 11.6 & $\mathrm{a}$ & 0.2 \\
\hline RS1332 & SF800 & 8.9 & $\mathrm{~b}$ & 0.8 & 9.2 & a & 0.8 & 57.4 & $\mathrm{a}$ & 2.5 & 76.6 & $\mathrm{a}$ & 2.8 & 11.6 & a & 0.2 & 11.9 & $\mathrm{ab}$ & 0.2 \\
\hline RS1332 & SS5244 & 8.8 & $\mathrm{~b}$ & 0.8 & 9.1 & $\mathrm{a}$ & 0.8 & 58.0 & $\mathrm{a}$ & 2.5 & 75.9 & $\mathrm{a}$ & 2.8 & 11.6 & $\mathrm{a}$ & 0.2 & 12.2 & $\mathrm{a}$ & 0.2 \\
\hline RS1332 & SS7167 & 11.4 & $\mathrm{ab}$ & 0.8 & 10.0 & $\mathrm{a}$ & 0.8 & 47.1 & $\mathrm{a}$ & 2.5 & 61.3 & $\mathrm{~b}$ & 2.8 & 10.9 & $\mathrm{ab}$ & 0.2 & 11.7 & $\mathrm{ab}$ & 0.2 \\
\hline RS1332 & SS7177 & 12.3 & $\mathrm{a}$ & 0.8 & 11.5 & $\mathrm{a}$ & 0.8 & 51.5 & $\mathrm{a}$ & 2.5 & 64.7 & $\mathrm{ab}$ & 2.8 & 10.6 & $\mathrm{~b}$ & 0.2 & 11.3 & $\mathrm{ab}$ & 0.2 \\
\hline RS1332 & SS7187 & 10.9 & $\mathrm{ab}$ & 0.8 & 10.8 & $\mathrm{a}$ & 0.8 & 51.1 & $\mathrm{a}$ & 2.5 & 67.3 & $a b$ & 2.8 & 10.8 & $\mathrm{ab}$ & 0.2 & 10.9 & $\mathrm{~b}$ & 0.2 \\
\hline $\mathrm{RS} 1420$ & SF800 & 9.4 & $\mathrm{a}$ & 0.9 & 11.9 & $\mathrm{a}$ & 0.8 & 53.7 & $\mathrm{a}$ & 3.1 & 72.0 & $\mathrm{a}$ & 2.8 & 12.0 & $\mathrm{a}$ & 0.3 & 11.8 & $a b$ & 0.2 \\
\hline $\mathrm{RS} 1420$ & SS5244 & 11.4 & $\mathrm{a}$ & 0.9 & 11.0 & $\mathrm{a}$ & 0.8 & 64.2 & $\mathrm{a}$ & 3.1 & 76.8 & $\mathrm{a}$ & 2.8 & 11.3 & $\mathrm{a}$ & 0.3 & 12.4 & $\mathrm{a}$ & 0.2 \\
\hline RS1420 & SS7167 & 12.3 & $\mathrm{a}$ & 0.9 & 13.4 & $\mathrm{a}$ & 0.8 & 49.5 & $\mathrm{a}$ & 3.1 & 73.2 & $\mathrm{a}$ & 2.8 & 11.3 & $\mathrm{a}$ & 0.3 & 12.3 & $\mathrm{a}$ & 0.2 \\
\hline RS1420 & SS7177 & 14.3 & $\mathrm{a}$ & 1.3 & 14.2 & $\mathrm{a}$ & 0.8 & 50.6 & $\mathrm{a}$ & 4.4 & 64.2 & $\mathrm{a}$ & 2.8 & 10.6 & a & 0.4 & 11.1 & $\mathrm{~b}$ & 0.2 \\
\hline $\mathrm{RS} 1420$ & SS7187 & 13.5 & $\mathrm{a}$ & 0.9 & 14.6 & $\mathrm{a}$ & 0.8 & 57.7 & $\mathrm{a}$ & 3.1 & 70.5 & $\mathrm{a}$ & 2.8 & 10.4 & $\mathrm{a}$ & 0.3 & 11.0 & $\mathrm{~b}$ & 0.2 \\
\hline RS1422 & SF800 & 9.4 & $\mathrm{c}$ & 0.8 & 9.4 & $\mathrm{a}$ & 0.8 & 57.9 & $\mathrm{a}$ & 2.5 & 72.8 & $\mathrm{a}$ & 2.8 & 11.8 & $\mathrm{a}$ & 0.2 & 11.8 & $a b$ & 0.2 \\
\hline RS1422 & SS5244 & 9.4 & $\mathrm{bc}$ & 0.9 & 9.6 & $\mathrm{a}$ & 0.8 & 56.8 & a & 3.1 & 68.8 & $\mathrm{a}$ & 2.8 & 11.6 & $\mathrm{ab}$ & 0.3 & 11.7 & $\mathrm{ab}$ & 0.2 \\
\hline RS1422 & SS7167 & 12.0 & $a b$ & 0.8 & 12.9 & $\mathrm{a}$ & 0.8 & 51.7 & $\mathrm{a}$ & 2.5 & 66.2 & $\mathrm{a}$ & 2.8 & 11.3 & $a b$ & 0.2 & 12.6 & $\mathrm{a}$ & 0.2 \\
\hline RS1422 & SS7177 & 11.8 & $a b c$ & 0.8 & 11.8 & $\mathrm{a}$ & 0.8 & 56.8 & $\mathrm{a}$ & 2.5 & 70.6 & $\mathrm{a}$ & 2.8 & 11.1 & $a b$ & 0.2 & 11.5 & $a b$ & 0.2 \\
\hline RS1422 & SS7187 & 12.4 & $\mathrm{a}$ & 0.8 & 11.6 & $\mathrm{a}$ & 0.8 & 54.1 & $\mathrm{a}$ & 2.5 & 70.0 & $\mathrm{a}$ & 2.8 & 11.1 & $\mathrm{~b}$ & 0.2 & 11.4 & $\mathrm{~b}$ & 0.2 \\
\hline none & SF800 & 8.8 & $\mathrm{c}$ & 0.8 & 9.4 & $a b$ & 0.8 & 49.8 & $\mathrm{a}$ & 2.5 & 74.6 & $\mathrm{a}$ & 2.8 & 11.8 & $\mathrm{a}$ & 0.2 & 11.9 & $\mathrm{~b}$ & 0.2 \\
\hline
\end{tabular}


(Appendix Table 5). Contd.....

\begin{tabular}{|c|c|c|c|c|c|c|c|c|c|c|c|c|c|c|c|c|c|c|c|}
\hline none & SS5244 & 8.9 & $\mathrm{bc}$ & 0.8 & 8.7 & $\mathrm{~b}$ & 0.8 & 56.6 & $\mathrm{a}$ & 2.5 & 76.1 & $\mathrm{a}$ & 2.8 & 11.7 & $\mathrm{a}$ & 0.2 & 12.7 & $\mathrm{a}$ & 0.2 \\
\hline none & SS7167 & 9.7 & $\mathrm{bc}$ & 0.8 & 10.8 & $a b$ & 0.8 & 49.6 & a & 2.5 & 66.5 & $\mathrm{a}$ & 2.8 & 11.3 & $\mathrm{a}$ & 0.2 & 12.4 & $a b$ & 0.2 \\
\hline none & SS7177 & 12.1 & a & 0.8 & 10.9 & $a b$ & 0.8 & 50.3 & $\mathrm{a}$ & 2.5 & 68.3 & a & 2.8 & 11.3 & $\mathrm{a}$ & 0.2 & 11.6 & $\mathrm{~b}$ & 0.2 \\
\hline none & SS7187 & 10.9 & $\mathrm{ab}$ & 0.8 & 11.4 & a & 0.8 & 54.2 & $\mathrm{a}$ & 2.5 & 71.9 & $\mathrm{a}$ & 2.8 & 11.5 & $\mathrm{a}$ & 0.2 & 11.9 & $\mathrm{~b}$ & 0.2 \\
\hline none & Jamboree & 7.5 & $\mathrm{a}$ & 0.7 & 7.9 & $\mathrm{a}$ & 0.7 & 47.5 & $\mathrm{~b}$ & 2.2 & 64.5 & $\mathrm{a}$ & 2.5 & 11.7 & $\mathrm{a}$ & 0.2 & 11.8 & $a b$ & 0.2 \\
\hline none & Jubilee & NT & & & 7.9 & a & 1.0 & NT & & & 62.5 & a & 3.5 & NT & & & 11.2 & $\mathrm{~b}$ & 0.3 \\
\hline none & Royal Sweet & 7.8 & $\mathrm{a}$ & 0.9 & 6.2 & $\mathrm{~b}$ & 0.8 & 45.2 & $\mathrm{~b}$ & 3.1 & 58.5 & $\mathrm{a}$ & 2.8 & 11.6 & $\mathrm{a}$ & 0.3 & 12.3 & $\mathrm{a}$ & 0.2 \\
\hline none & Sangria & 8.7 & $\mathrm{a}$ & 0.6 & 8.0 & $\mathrm{a}$ & 0.6 & 53.2 & $\mathrm{a}$ & 1.9 & 66.4 & $\mathrm{a}$ & 2.0 & 11.4 & $\mathrm{a}$ & 0.2 & 11.9 & $a b$ & 0.2 \\
\hline
\end{tabular}

Values in Table are least square means with pooled standard errors in rootstock groupings. Means followed by same letters within a cultivar group within a column are not significantly different at $\mathrm{P} \leq 0.05$ using Tukey's adjusted means comparison.

NT: not tested.

Watermelon production has become more sophisticated in the past thirty years as the industry has evolved from openpollinated diploids to hybrid diploids and ultimately to triploids with diploid pollinator plants [3]. The fresh-cut industry in the United States has grown dramatically in the last 10 years and makes up almost $30 \%$ of the total watermelon sold (National Watermelon Promotion Board, personal communication). While watermelon may be purchased as halves or quarters with a portion of the rind remaining, most of the fresh-cut watermelon is sold as small chunks (without rind) in plastic containers where fruit firmness is a major concern for extended shelf-life. In addition to achieving increased disease resistance in the plant, the enhanced fruit firmness of grafted watermelon fruit may contribute significantly to the fresh-cut industry.

\section{ACKNOWLEDGEMENTS}

The authors wish to acknowledge the technical support and/or helpful suggestions of Diann Baze, Rick Houser, Wyatt O'Hern, and Angela Davis. The authors also wish to acknowledge the grafting provided by Speedling Inc., Alamo, Texas and Abbott \& Cobb Seed Co., Trevose, Pennsylvania for providing scion and rootstock seed.

\section{REFERENCES}

[1] Anonymous. Report of the ninth meeting of the parties to the Montreal protocol on substances that deplete the ozone layer. Montreal, Canada: United Nations Environment Programme 1997; pp. 1-47.

[2] Bruton BD. Soilborne diseases in Cucurbitaceae: Pathogen virulence and host resistance. In: McCreight J, Ed. Cucurbitaceae ' 98. Alexandria, VA: ASHS Press 1998; pp. 143-66.

[3] Bruton BD, Fish WW, Zhou XG, Everts KL, Roberts PD. Fusarium wilt in seedless watermelons. In: Kelley WT, Ed. Proceeding 2007 Southeast Regional Vegetable Conference, 2007: Savannah, Georgia 2007; pp. 93-8.

[4] Oda M. Grafting of vegetables to improve greenhouse production. Ext Bull Food Fert Tech Center 1999; 480: 11.

[5] Lee JM. Cultivation of grafted vegetables I. Current status, grafting methods and benefits. Hortic Sci 1994; 29: 235-9.

[6] Lee JM, Bang HJ, Ham HS. Grafting of vegetables. J Jpn Soc Hortic Sci 1998; 67: 1098-104.

[7] Taylor M, Bruton B, Fish W, Roberts W. Cost benefits of using grafted watermelon transplants for Fusarium wilt disease control. Acta Hortic 2008; 782: 343-50.

[8] Rivero RM, Ruiz JM, Romero L. Role of grafting in horticultural plants under stress conditions. Food Agric Environ 2003; 1: 70-4.

[9] Ryu JS, Choi KS, Lee SS. Effect of grafting stocks on growth, quality and yields of watermelon. J Kor Soc Hortic Sci 1973; 13: $45-9$.
[10] Alexopoulos AA, Kondylis A, Passam H. Fruit yield and quality of watermelon in relation to grafting. J Food Agric Environ 2007; 5: 178-9.

[11] Qian QQ, Liu HY, Liu HY, Zhu ZH. Studies on sugar metabolism and related enzymes activity during watermelon fruit development as influenced by grafting. Zhejiang Univ J Agric Life Sci 2004; 30: 285-9.

[12] Lopez-Galarza S, San Bautista A, Perez DM, et al. Effects of grafting and cytokinin-induced fruit setting on color and sugar-content traits in glasshouse-grown triploid watermelon. J Hortic Sci Biotechnol 2004; 79: 971-6.

[13] Colla G, Rouphael Y, Cardarelli M, Rea E. Effect of salinity on yield, fruit quality, leaf gas exchange, and mineral composition of grafted watermelon plants. Hortic Sci 2006; 41: 622-7.

[14] Miguel A, Maroto JV, San Bautista A, et al. The grafting of triploid watermelon is an advantageous alternative to soil fumigation by methyl bromide for control of Fusarium wilt. Sci Hortic 2004; 103: 9-17.

[15] Liu RQ, Zhang HM, Xu JH, et al. Effects of rootstocks on growth and fruit quality of grafted watermelon. J Shanghai Jiaotong Univ Agric Sci 2003; 21: 289-94.

[16] Yetisir H, Sari N, Yucel S. Rootstock resistance to Fusarium wilt and effect on watermelon fruit yield and quality. Phytoparasitica 2003; 31: 163-9.

[17] Huh YC, Woo YH, Lee JM, Om YH. Growth and fruit characteristics of watermelon grafted onto Citrullus rootstocks selected for disease resistance. J Kor Soc Hortic Sci 2003; 44: 649-54.

[18] Pulgar G, Villora G, Moreno DA, Romero L. Improving the mineral nutrition in grafted watermelon plants: nitrogen metabolism. Biol Plant 2000; 43: 607-9.

[19] Yetisir H, Sari N. Effect of different rootstock on plant growth, yield and quality of watermelon. Aust J Exp Agric 2003; 43: 126974.

[20] Di Mascio P, Kaiser S, Sies H. Lycopene as the most efficient biological carotenoid singlet oxygen quencher. Arch Biochem Biophys $1989 ; 274: 532-8$.

[21] Bohm V, Bitsch R. Intestinal absorption of lycopene from different matrices and interactions to other carotenoids, the lipid status, and the antioxidant capacity of human plasma. Eur J Nutr 1999; 38: $118-25$.

[22] Gann PH, Ma J, Giovannucci E, et al. Lower prostate cancer risk in men with elevated plasma lycopene levels: results of a prospective analysis. Cancer Res 1999; 59: 1225-30.

[23] Levy J, Bosin E, Feldman B, et al. Lycopene is a more potent inhibitor of human cancer cell proliferation than either $\alpha$-carotene or $\beta$-carotene. Nutr Cancer 1995; 24: 257-67.

[24] Hadley CW, Miller EC, Schwartz SJ, Clinton SK. Tomatoes, lycopene, and prostate cancer: Progress and promise. Exp Biol Med 2002; 227: 869-80.

[25] Giovannucci E. Tomatoes, tomato-based products, lycopene, and cancer: Review of the epidemiologic literature. J Natl Cancer Inst 1999; 91: 317-31.

[26] Klipstein-Grobusch K, Launer LJ, Geleijnse JM, Boeing H, Hofman A, Witteman JC. Serum carotenoids and atherosclerosis. The Rotterdam Study. Atherosclerosis 2000; 148: 49-56. 
[27] Rissanen TH, Voutilainen S, Nyyssonen K, Salonen R, Kaplan GA, Salonen JT. Serum lycopene concentrations and carotid atherosclerosis: the Kuopio Ischaemic heart disease risk factor study. Am J Clin Nutr 2003; 77: 133-8.

[28] Sesso HD, Buring JE, Norkus EP, Gaziano JM. Plasma lycopene, other carotenoids, and retinol and the risk of cardiovascular disease in women. Am J Clin Nutr 2004; 79: 47-53.

[29] Kavanaugh CJ, Trumbo PR, Ellwood KC. The US food and drug administration's evidence-based review for qualified health claims: tomatoes, lycopene, and cancer. J Natl Cancer Inst 2007; 99: $1074-85$.

[30] Gartner C, Stahl W, Sies H. Lycopene is more bioavailable from tomato paste than from fresh tomatoes. Am J Clin Nutr 1997; 66: 116-22.

[31] Bohm V, Frohlich K, Bitsch R. Rosehip - a "new" source of lycopene? Mol Aspects Med 2003; 24: 385-9.

[32] Perkins-Veazie P, Collins JK, Pair SD, Roberts W. Lycopene content differs among red-fleshed watermelon cultivars. J Sci Food Agric 2001; 81: 983-7.

[33] Fish WW, Perkins-Veazie P, Collins JK. A quantitative assay for lycopene that utilizes reduced volumes of organic solvents. J Food Comp Anal 2002; 15: 309-17.

[34] Yamasaki A, Yamashita M, Furuya S. Mineral concentrations and cytokinin activity in the xylem exudates of grafted watermelons as affected by rootstocks and crop load. J Jpn Soc Hortic Sci 1994; 62: 817-26.
[35] Proietti S, Rouphael Y, Colla G, et al. Fruit quality of miniwatermelon as affected by grafting and irrigation regimes. J Sci Food Agric 2008; 88: 1107-14.

[36] Chouka AS, Jebari H. Effect of grafting on watermelon vegetative and root development, production and fruit quality. Acta Hortic 1999; 492: 85-93.

[37] Alan O, Ozdemir N, Funen Y. Effect of grafting on watermelon plant growth, yield and quality. J Agron 2007; 6: 362-5.

[38] United States Department of Agriculture-Agricultural Marketing Service. United States Standards for Grades of Watermelon. Washington, DC; 1997 [Cited 2008 July17]. Available from: www.ams.usda.gov/AMSv1.0/getfile?dDocName=STELPRDC505 0334 [PDF]

[39] Mondal SN, Amzad Hossain AKM, Hossain AE, Islam MA, Bashar MA. Effect of various rootstocks in the graft culture of watermelon in Bangladesh. Punjab Veg Grower 1994; 29: 15-9.

[40] Salam MA, Masum ASMH, Chowdhury SS, Dhar M, Saddeque MA, Islam MR. Growth and yield of watermelon as influenced by grafting. Online J Bio Sci 2002; 2: 298-9.

[41] Hwang H, Ko KD, Son JI. Study on development of automatic grafting system for fruit bearing vegetable seedlings. Ministry Agric and Forestry Agric Spec Res Rpt 1995; pp. 1-68.

[42] Lee JM, Oda M. Grafting of herbaceous vegetable and ornamental crops. Hortic Rev 2003; 8: 61-87.

Received: October 16, 2008

Revised: November 04, 2008

Accepted: November 14, 2008

(C) Bruton et al.; Licensee Bentham Open.

This is an open access article licensed under the terms of the Creative Commons Attribution Non-Commercial License (http://creativecommons.org/licenses/by-nc/3.0/) which permits unrestricted, non-commercial use, distribution and reproduction in any medium, provided the work is properly cited. 